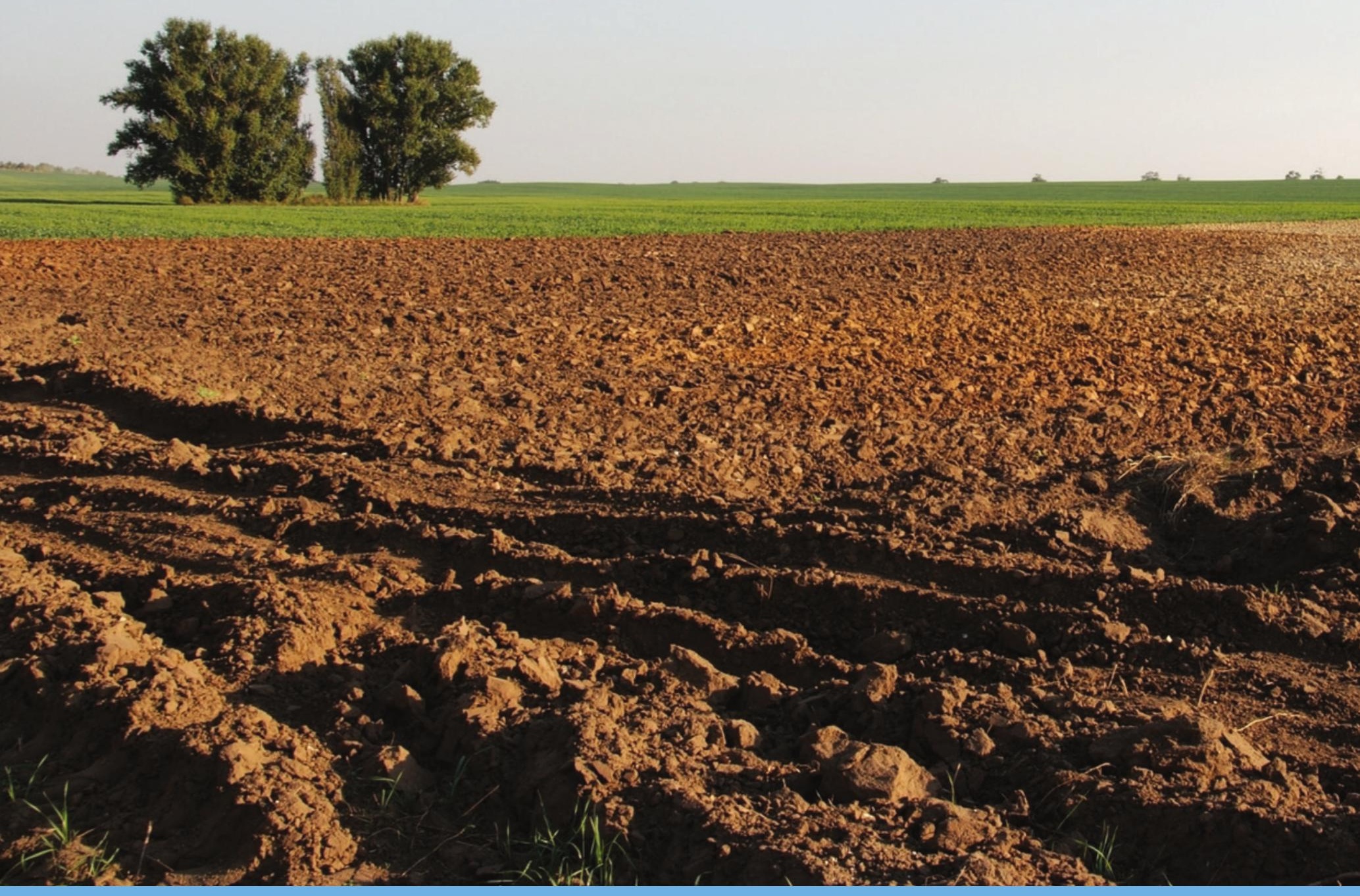

\title{
Herkomstanalyse gewasbeschermingsmiddelen in het grondwater van de Provincie Drenthe
}

Meetperiode 2002-2007

Roel Kruijne, Jan Groenwold

WAGENINGEN

UNIVERSITY \& RESEARCH 



\section{Herkomstanalyse gewasbeschermingsmiddelen in het grondwater van de Provincie Drenthe}

Meetperiode 2002-2007

Roel Kruijne, Jan Groenwold

Dit onderzoek is in 2008 uitgevoerd door Wageningen Environmental Research (Alterra) in opdracht van en gefinancierd door Provincie Drenthe.

Wageningen Environmental Research

Wageningen, mei 2017

Rapport 2815

ISSN 1566-7197 
Roel Kruijne, Jan Groenwold, 2017. Herkomstanalyse gewasbeschermingsmiddelen in het grondwater van de Provincie Drenthe; Meetperiode 2002-2007. Wageningen, Wageningen Environmental Research, Rapport 2815. 42 blz.; 7 fig.; 17 tab.; 10 ref.

In 2008 heeft WEnR-Alterra een analyse gegeven van de mogelijke herkomst van gewasbeschermingsmiddelen die in de jaren 2002, 2004, 2006 en 2007 zijn aangetroffen in het grondwater van de Provincie Drenthe. Ruim de helft van de geanalyseerde gewasbeschermingsmiddelen is niet (meer) toegelaten op de Nederlandse markt. Veel stoffen hebben een brede toepassing (gehad) in meerdere sectoren en daarnaast ook buiten de landbouw. De breedte van deze toepassingen en de wijzigingen in de tijd beperken de mogelijkheid om het voorkomen van een stof in verband te brengen met een specifiek gebruik. Uit regionale berekeningen blijkt dat het grondwater in de Provincie Drenthe als geheel minder kwetsbaar is voor uitspoeling van stoffen dan het grondwater in Nederland. Uit berekeningen met lokale invoergegevens blijkt, dat de meest kwetsbare locaties voor uitspoeling van de stof bentazon zijn oververtegenwoordigd in de bemonstering.

Trefwoorden: gewasbeschermingsmiddel, bestrijdingsmiddel, pesticide, monitoring, grondwater, uitspoeling, LMG, PMG, GeoPEARL

Dit rapport is gratis te downloaden van http://dx.doi.org/10.18174/415731 of op www.wur.nl/environmental-research (ga naar 'Wageningen Environmental Research' in de grijze balk onderaan). Wageningen Environmental Research verstrekt geen gedrukte exemplaren van rapporten.

() 2017 Wageningen Environmental Research (instituut binnen de rechtspersoon Stichting Wageningen Research), Postbus 47, 6700 AA Wageningen, T 03174807 00, E info.alterra@wur.nl, www.wur.nl/environmental-research. Wageningen Environmental Research is onderdeel van Wageningen University \& Research.

- Overname, verveelvoudiging of openbaarmaking van deze uitgave is toegestaan mits met duidelijke bronvermelding.

- Overname, verveelvoudiging of openbaarmaking is niet toegestaan voor commerciële doeleinden en/of geldelijk gewin.

- Overname, verveelvoudiging of openbaarmaking is niet toegestaan voor die gedeelten van deze uitgave waarvan duidelijk is dat de auteursrechten liggen bij derden en/of zijn voorbehouden.

Wageningen Environmental Research aanvaardt geen aansprakelijkheid voor eventuele schade voortvloeiend uit het gebruik van de resultaten van dit onderzoek of de toepassing van de adviezen. 


\section{Inhoud}

$\begin{array}{ll}\text { Woord vooraf } & 5\end{array}$

$\begin{array}{ll}\text { Samenvatting } & 7\end{array}$

1

Inleiding

9

1.1 Aanleiding 9

1.2 Doelstelling 9

$\begin{array}{lll}1.3 \text { Werkwijze } & 9\end{array}$

$\begin{array}{llr}1.4 & \text { Leeswijzer } & 10\end{array}$

2

$\begin{array}{ll}\text { Gegevens } & 11\end{array}$

$2.1 \quad$ Monitoring in het grondwater $\quad 11$

2.1.1 Locaties en analyses 11

2.1.2 Resultaten 11

2.2 Locatiekenmerken $\quad 12$

2.2.1 Grondgebruik 12

2.2.2 Bodem 13

$\begin{array}{lll}2.3 \text { Gebruik } & 13\end{array}$

2.4 Stofeigenschappen 14

$\begin{array}{lll}2.5 & \text { Uitspoeling van stoffen } & 14\end{array}$

2.5.1 Regionale berekeningen $\quad 14$

$\begin{array}{ll}2.5 .2 \text { Lokale berekeningen } & 15\end{array}$

$\begin{array}{llr}3 & \text { Resultaten en discussie } & 16\end{array}$

$\begin{array}{lll}3.1 & \text { Monitoring } & 16\end{array}$

$\begin{array}{lll}3.2 & \text { Locatiegegevens } & 18\end{array}$

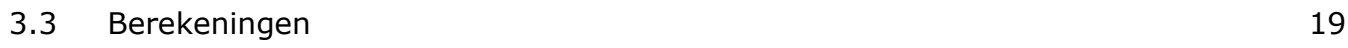

$\begin{array}{ll}3.3 .1 \text { Regionaal } & 19\end{array}$

$\begin{array}{ll}3.3 .2 \text { Lokaal } & 20\end{array}$

4 Conclusies en aanbevelingen $\quad 23$

$\begin{array}{ll}\text { Literatuur } & 25\end{array}$

Bijlage 1 Monitoringsresultaten grondwater Drenthe 26

Bijlage 2 Locatiekenmerken 31

Bijlage 3 Gebruik van stoffen $\quad 35$

$\begin{array}{lll}\text { Bijlage } 4 & \text { Stofparameters } & 37\end{array}$

$\begin{array}{lll}\text { Bijlage } 5 & \text { Resultaten uitspoelingsberekeningen } & 38\end{array}$ 



\section{Woord vooraf}

In het jaar 2008 heeft de Provincie Drenthe aan Wageningen Environmental Research (Alterra) opdracht gegeven om een analyse te maken van de mogelijke herkomst van werkzame stoffen en afbraakproducten van gewasbeschermingsmiddelen die in het grondwater zijn gemeten.

Bij de uitvoering van dit onderzoek werd dankbaar gebruik gemaakt van de adviezen van dhr. A.M.A. van der Linden (Rijksinstituut voor Volksgezondheid en Milieu/RIVM).

Voorliggend rapport over dit onderzoeksproject werd in 2008 opgeleverd. Om de resultaten beter te ontsluiten, werd in 2017 besloten om het uit te brengen in de reeks rapporten van Wageningen Environmental Research (Alterra).

Roel Kruijne 


\section{Samenvatting}

In Nederland zijn de provincies verantwoordelijk voor het uitvoeren van de monitoring van het grondwater die is voorgeschreven vanuit de Europese Kaderrichtlijn Water (KRW). De Provincie Drenthe heeft WUR-Alterra gevraagd om een analyse te geven van de mogelijke herkomst van stoffen die in de jaren 2002, 2004, 2006 en 2007 zijn aangetroffen in het grondwater van de Provincie Drenthe.

Deze herkomstanalyse is gebaseerd op een vergelijking van de meetgegevens met een aantal kenmerken van de bemonsteringslocaties en met de resultaten van modelberekeningen ter bepaling van het uitspoelingsrisico voor het grondwater. Er zijn een aantal aanbevelingen voor toekomstige monitoringsactiviteiten geformuleerd.

De meetgegevens zijn door de Provincie Drenthe aan WUR-Alterra verstrekt. Deze gegevens hebben betrekking op 31 stoffen, waaronder 24 stoffen die een registratie hebben (gehad) als gewasbeschermingsmiddel en 3 metabolieten. In het grondwater van de Provincie Drenthe zijn 8 werkzame stoffen en metabolieten één of meerdere keren aangetoond (2,6\% van het totaal aantal analyses). De werkzame stof bentazon is het meest aangetoond (16 keer of $17 \%$ van het aantal analyses op bentazon), gevolgd door diuron (8\%), ethofumesaat (5\%), chloridazon (4\%), metalaxyl $(3 \%)$, en mecoprop-p (2\%).

Ruim de helft van de geanalyseerde gewasbeschermingsmiddelen zijn niet (meer) toegelaten op de Nederlandse markt. Veel stoffen hebben een toepassing (gehad) in een aantal grote teelten binnen de akkerbouw, de veehouderij en in een aantal andere landbouwsectoren. Daarnaast zijn veel stoffen ook buiten de landbouw toegepast. De breedte van deze toepassingen en de wijzigingen in de loop der jaren beperken de mogelijkheid om het voorkomen van een stof in het grondwater in verband te brengen met een specifiek gebruik.

Gegevens van de bemonsteringslocaties uit het Provinciaal Meetnet Grondwaterkwaliteit/PMG zijn aangevuld aan de hand van LGN-grondgebruikskaarten en de Bodemkaart van Nederland. Uit een inventarisatie van 4 achtereenvolgende opnames van het grondgebruik blijkt dat er geen permanent onderscheid valt te maken tussen bemonsteringslocaties op bouwland en op grasland. De mogelijkheden, om op basis van locatiekenmerken van het meetnet een verdere optimalisatie in de monitoring van het grondwater te bereiken, zijn zeer beperkt.

Om het uitspoelingsrisico voor het grondwater in de Provincie Drenthe en op de bemonsteringslocaties te bepalen zijn berekeningen uitgevoerd met het model GeoPEARL 3.3.3. Dit model wordt gebruikt in de beoordeling van toelatingsaanvragen op het onderdeel uitspoeling. Uit regionale berekeningen blijkt dat het grondwater in de Provincie Drenthe als geheel minder kwetsbaar is voor uitspoeling van stoffen dan het grondwater in Nederland. De resultaten van berekeningen met lokale invoergegevens geven een beeld van het uitspoelingsrisico op de bemonsteringslocaties. Dit risico blijkt sterk te variëren met het gehalte organische stof en de mate waarin het grondwater vanuit de bouwvoor wordt aangevuld.

Voor de stof bentazon is de representativiteit van de bemonsteringslocaties voor de Provincie Drenthe in beeld gebracht voor wat betreft het uitspoelingsrisico. Het blijkt dat de combinaties van bodem en hydrologie met het grootste uitspoelingsrisico zijn oververtegenwoordigd in de bemonstering. Voor de stof bentazon is er een relatie tussen de berekende lokale uitspoelingsgevoeligheid, en de bemonsteringslocaties waar deze stof is aangetoond. Deze relatie is afhankelijk van de stofeigenschappen en kan per stof verschillend zijn.

Uit het overzicht van de meetgegevens van het grondwater in de Provincie Drenthe is geconcludeerd dat de resultaten van 2007 een bevestiging zijn van de resultaten uit 2006. Er zijn geen nieuwe 
inzichten uit de resultaten van de laatste ronde naar voren gekomen. Dit ligt in de lijn der verwachtingen omdat gedeeltelijk hetzelfde water (afkomstig van dezelfde toepassingen) is bemonsterd. Gegeven de diepte en de lengte van de filters is het niet zinvol om vaker dan ééns per 2 jaar monsters te analyseren op gewasbeschermingsmiddelen. Om deze reden wordt aanbevolen om de komende 2-3 jaar geen bemonstering op dezelfde locaties uit te voeren. Eventueel, als er meer putten zijn, dan zou bemonstering daarvan wel overwogen kunnen worden.

Op dit moment is de Werkgroep Validatie Beslisboom Uitspoeling (Alterra-RIVM-PBL-VEWIN-Ctgb) actief. Deze werkgroep toetst of de huidige beslisboom uitspoeling het grondwater in Nederland voldoende beschermt. Voor wat betreft de stoffen bentazon en mecoprop-p wordt aanbevolen om de rapportage van de Werkgroep Validatie Beslisboom Uitspoeling en/of eventuele ontwikkelingen omtrent de toelating af te wachten.

In de Provincie Drenthe zijn de meeste stoffen aangetoond in de monsters van het grondwater in de ondiepe filters. Over het algemeen zal dit water op een recenter tijdstip geïnfiltreerd zijn dan het grondwater in het diepe filter. Geadviseerd wordt om beter in te spelen op de ontwikkelingen in het agrarisch grondgebruik en de daarmee samenhangende veranderingen in het middelengebruik in de landbouw. Dit valt te realiseren door over te stappen naar een bemonstering van het bovenste grondwater.

Aanbevolen wordt om in de opzet van een nieuwe monitoringsronde bij de keuze van het stoffenpakket rekening te houden met de resultaten van eerdere inventarisaties van het gebruik in de landbouw en daarbuiten, en met de resultaten van een analyse van de mogelijke herkomst van probleemstoffen in de Provincie Drenthe en andere regio's.

Ongeveer 2/3 van de aangetoonde stoffen in de Provincie Drenthe en de overige Noordelijke provincies is medio 2008 niet meer toegelaten. Aanbevolen wordt om in volgende bemonsteringsronden minder analyses aan deze stoffen te besteden.

Tenslotte wordt geadviseerd om na te gaan of er specifieke omstandigheden zijn die hebben geleid tot het aantreffen van stoffen. Locaties waar meerdere stoffen tegelijkertijd zijn aangetroffen komen hiervoor het eerste in aanmerking. 


\section{$1 \quad$ Inleiding}

\section{$1.1 \quad$ Aanleiding}

In Nederland zijn de provincies verantwoordelijk voor het uitvoeren van de monitoring van het grondwater die is voorgeschreven vanuit de Europese Kaderrichtlijn Water (KRW). In het grondwater in de Provincie Drenthe worden regelmatig werkzame stoffen en afbraakproducten van een aantal gewasbeschermingsmiddelen aangetroffen. Een aantal provincies heeft besloten om in 2006 een bemonstering van het grondwater te laten uitvoeren en de resultaten voor de KRWrapportageverplichting te gebruiken (nulmeting). Ook in 2007 is in een aantal provincies een bemonstering van het grondwater uitgevoerd.

In samenwerking met de waterbeheerders en drinkwaterbedrijven, de agrarische sector en overige gebruikers van gewasbeschermingsmiddelen speelt de Provincie Drenthe een actieve rol in de ontwikkeling van aanvullend beleid om te komen tot een verbetering van de kwaliteit van het oppervlaktewater en het grondwater. De Provincie Drenthe heeft Alterra gevraagd om een analyse te geven van de mogelijke herkomst van stoffen die in het grondwater van de Provincie Drenthe zijn aangetroffen.

\subsection{Doelstelling}

Het doel van het onderzoek is om de mogelijke herkomst te bepalen van gemeten werkzame stoffen en metabolieten van gewasbeschermingsmiddelen in het grondwater van de Provincie Drenthe. Tevens wordt een aantal aanbevelingen gedaan voor toekomstige monitoring van gewasbeschermingsmiddelen in het grondwater.

\subsection{Werkwijze}

Deze herkomstanalyse is gebaseerd op een vergelijking van meetgegevens met een aantal locatiekenmerken en met de resultaten van modelberekeningen.

In het voorliggend onderzoek zijn lokale bodem- en grondgebruiksgegevens en originele meetnetgegevens gebruikt om het uitspoelingsrisico globaal aan te geven. Resultaten van modelberekeningen voor een standaard toediening van de geanalyseerde stoffen zijn gebruikt om het beeld van het uitspoelingsrisico verder in te vullen.

Op basis van modelberekeningen wordt een uitspraak gedaan over het uitspoelingsrisico voor het grondwater in de Provincie Drenthe als geheel, en in de meetlocaties. Er volgt een interpretatie aan de hand van vergelijking met de meetresultaten, waaruit enkele conclusies en aanbevelingen voor een vervolg op de recente monitoringsaktiviteiten worden geformuleerd. 


\subsection{Leeswijzer}

In Hoofdstuk 2 van het voorliggend rapport is een korte beschrijving van de monitoringsresultaten van de Provincie Drenthe gegeven. Het hoofdstuk vervolgt met een beschrijving van het grondgebruik, de bodemgegevens en andere kenmerken van de bemonsteringslocaties, met de (historische) toepassingen van de geanalyseerde gewasbeschermingsmiddelen, en met de opzet van de modelberekeningen. In Hoofdstuk 3 worden de monitoringsresultaten besproken in relatie tot de locatiegegevens en de resultaten van de modelberekeningen. Hoofdstuk 4 bevat de conclusies en een aantal aanbevelingen voor toekomstige monitoring.

In het voorliggend rapport wordt de term grondwater gebruikt voor het water dat zich op de diepte van het ondiepe filter van de bemonsteringsputten bevindt; op de meeste locaties is dat op ca. $10 \mathrm{~m}$ diepte. Met de term diep grondwater wordt het water bedoeld dat zich op de diepte van het diepe filter bevindt (ca. $25 \mathrm{~m}$ diepte).

Het resultaat van een analyse is 'aangetoond' of 'gemeten' bij een concentratie groter dan of gelijk aan de detectielimiet. 


\section{Gegevens}

\subsection{Monitoring in het grondwater}

In dit onderzoek zijn alle analyseresultaten van monsters van het grondwater in de Provincie Drenthe meegenomen. Deze monsters zijn in 2002, 2004, 2006 en 2007 verzameld door medewerkers van de Provincie Drenthe, onder verantwoordelijkheid van het Waterlaboratorium Noord/WLN. De monsters zijn geanalyseerd door het WLN $(2002,2004)$ en door het laboratorium Omegam $(2006,2007)$. Eventuele verschillen in rapportage en notaties in de originele bestanden van Omegam zijn door Alterra geëlimineerd en de resultaten zijn in een database opgenomen. De meeste analyses zijn uit 2006 en 2007. In Bijlage 1 is een aantal overzichten van de resultaten opgenomen.

Op meetlocaties in de provincies Friesland, Groningen en Overijssel zijn ook monsters van het grondwater genomen. In 2006 zijn de monsters in deze provincies verzameld door Tauw Noord. In 2007 zijn de monsters in alle vier de provincies verzameld door de monsternemers van de Provincie Drenthe. De monsters zijn door Omegam op dezelfde stoffen geanalyseerd als in Drenthe.

Binnen de provincies zijn tussen de meetjaren 2006 en 2007 verschillen in resultaten waargenomen. Deze verschillen waren het grootst in de provincies Friesland, Groningen en Overijssel. Nu wordt verondersteld dat deze verschillen zijn terug te voeren op de wijze van bemonstering door de monsternemers van TAUW (Friesland, Groningen en Overijssel) en van de Provincie Drenthe (persoonlijke mededeling Anton Dries, Provincie Drenthe). Overeenkomstige resultaten uit de bemonsteringsronden van 2006 en 2007 liggen in de lijn der verwachtingen; gezien de lengte van de filters wordt in twee opeenvolgende jaren gedeeltelijk hetzelfde grondwater bemonsterd.

Deze herkomstanalyse heeft betrekking op werkzame stoffen en metabolieten van gewasbeschermingsmiddelen die zijn opgenomen in de database van de Nationale Milieu Indicator/NMI 2. De resultaten van de metingen in de Provincies Friesland, Groningen en Overijssel worden uitsluitend meegenomen in de bespreking van de resultaten en de discussie.

\subsubsection{Locaties en analyses}

De monsters zijn op 40 locaties in de Provincie Drenthe genomen; meestal van het grondwater in het ondiepe filter (filternr. 1 op ca. 10 meter diepte) en het diepe filter van de put (filternr. 3 op ca. 25 meter diepte). De meeste monsters waarin een of meerdere stoffen zijn aangetoond zijn afkomstig van het grondwater in het ondiepe filter. Dit geldt ook voor het percentage aangetoond per filter (in procenten van het aantal analyses per filter).

\subsubsection{Resultaten}

Er zijn 31 stoffen geanalyseerd, waarvan 24 stoffen die een registratie hebben (gehad) als gewasbeschermingsmiddel en 3 metabolieten.

In het grondwater van de Provincie Drenthe is 68 keer een stof aangetoond $(2,6 \%$ van het totaal aantal analyses). Er zijn 8 werkzame stoffen en metabolieten van gewasbeschermingsmiddelen aangetoond. De werkzame stof bentazon is het meest aangetoond (16 keer of $17 \%$ van het aantal analyses op bentazon), gevolgd door diuron ( 8 keer of $8 \%$ van het aantal analyses op diuron) en ethofumesaat ( 5 keer of $5 \%$ van het aantal analyses op ethofumesaat). De overige werkzame stoffen zijn chloridazon, metalaxyl, en mecoprop- $\mathrm{p}^{1}$. Tabel 1 bevat een overzicht van het aantal keer dat

\footnotetext{
${ }^{1}$ Vermoedelijk is mecoprop gemeten, maar waarschijnlijk is het afkomstig van een toepassing met mecoprop-p. Mecoprop en mecoprop-p zijn optische isomeren die in elkaar kunnen worden omgezet.
} 
stoffen zijn aangetoond in het grondwater van de Provincie Drenthe, inclusief de herkomst van de monsters (het aantal locaties).

Tabel 1 Het aantal aangetoond en het aantal locaties in het grondwater van de Provincie Drenthe (monitoring 2002, 2004, 2006 en 2007).

\begin{tabular}{|c|c|c|}
\hline Stofnaam & aantal meetwaarden & aantal locaties \\
\hline \multicolumn{3}{|l|}{ Werkzame stof } \\
\hline Bentazon & 16 & 9 \\
\hline Ethofumesaat & 5 & 3 \\
\hline Chloridazon & 4 & 2 \\
\hline mecoprop-p & 2 & 1 \\
\hline \multicolumn{3}{|l|}{ Metaboliet } \\
\hline 2,6-dichlorobenzamide/BAM & 9 & 4 \\
\hline desethyl-atrazin & 4 & 2 \\
\hline Totaal & 68 & \\
\hline
\end{tabular}

Ook regelmatig aangetroffen is 2,6-dichlorobenzamide/BAM (9 keer of $10 \%$ van het aantal analyses op BAM). Deze metaboliet van dichlobenil heeft een niet-relevantverklaring. De stof desethyl-atrazin is een metaboliet van atrazin, dat sinds november 1999 niet meer is toegelaten. De stoffen 1,2-dichloorpropaan (een verontreiniging in het niet meer toegelaten grondontsmettingsmiddel 1,3-dichloorpropeen) en diethyltoluamide (bestanddeel in muggenolie) zijn geen gewasbeschermingsmiddel.

De maximum concentratie van de stoffen ethofumesaat, desethyl-atrazin en diethyltoluamide/DEET in de grondwatermonsters is lager dan de drinkwaternorm $(0,1 \mu \mathrm{g} / \mathrm{L})$. De maximum concentratie van de andere stoffen in Tabel 1 overschrijdt de drinkwaternorm.

\subsection{Locatiekenmerken}

Van 23 locaties uit het Provinciaal Meetnet Grondwaterkwaliteit/PMG zijn locatiegegevens verstrekt door de Provincie Drenthe. Dit betreft onder meer de uitslag van een bepaling van de ouderdom van het grondwater, de grondsoort en bodemeenheid, het grondwaterregime (Gt-klasse), de interactie met het grondwater (kwel, infiltratie, intermediair), en het bodemgebruik (bouwland, grasland, bos/natuur). Van 13 locaties zijn een aantal locatiegegevens uit het Landelijk Meetnet Grondwaterkwaliteit/LMG gebruikt. Het geheel is aangevuld aan de hand van de LGNgrondgebruikskaarten en de Bodemkaart van Nederland (Bijlage 2).

Omdat vorm en omvang van het intrekgebied niet bekend zijn, is in deze studie gebruik gemaakt van bodem- en grondgebruiksgegevens in een straal van $50 \mathrm{~m}$ rond de meetlocatie. In werkelijkheid kan het bemonsterde grondwater gedeeltelijk of geheel op een grotere afstand van de put geïnfiltreerd zijn.

\subsubsection{Grondgebruik}

Informatie over het grondgebruik in de directe omgeving van de meetlocaties kan inzicht geven in het mogelijke gebruik van gewasbeschermingsmiddelen. In het algemeen is de periode tussen het moment van infiltratie en het bemonsteringstijdstip niet bekend. Om deze reden zijn verschillende opnames van het grondgebruik op dezelfde locaties verzameld. In de versies $2 \mathrm{t} / \mathrm{m} 5$ van het Landelijk 
Grondgebruiksbestand/LGN zijn de gegevens van de Provincie Drenthe gebaseerd op satellietbeelden uit 1992, 1997, 2000 en 2004. Van 32 locaties zijn de locatiegegevens aangevuld met deze vier opnames van het grondgebruik. In de 8 overige locaties zijn alleen gegevens van de opname uit 2004 gebruikt (LGN4).

\subsubsection{Bodem}

Het uitspoelingsrisico wordt vooral bepaald door het gehalte organische stof in de bodem. Om deze reden zijn de bodemeenheden in een straal van $50 \mathrm{~m}$ rond de meetlocatie gegroepeerd aan de hand van het organischestofprofiel in de laag tot $1.2 \mathrm{~m}$ diepte (volgens de Bodemkaart van Nederland, schaal 1 : 50 000). Naast het gehate organische stof kunnen ook de pH van de bodem en de hydrologische omstandigheden van belang zijn voor het uitspoelingsrisico van stoffen. Overige relevante informatie in de bodemkaart betreft de aanwezigheid van associaties van minerale- en moerige gronden, en eventuele opmerkingen over de degradatie en de status van het veen (uit de herkartering 2004). Degradatie van het veen kan namelijk een vergroting van het uitspoelingsrisico binnen het intrekgebied tot gevolg hebben.

Voor elke locatie is de dominante kaarteenheid gekozen binnen de 50 m-buffer (32 locaties) of in een gebied van ongeveer dezelfde grootte (8 locaties o.b.v. LGN4). Er zijn 11 locaties met een oppervlakte veen of moerige grond in de directe omgeving. In 6 van deze locaties met een associatie bestaand uit minerale grond en veengrond, of met de opmerking 'Onzekerheid over de status moerige grond', of 'Gedegradeerde veengrond (2004)' bij de dominante bodemeenheid, is de minerale grond als de representatieve bodemeenheid gekozen. Uit het overzicht in Tabel 2 met 6 combinaties van organischestof- en Gt-klasse blijkt dat de meeste locaties in de Provincie Drenthe op zandgronden liggen.

Tabel 2 Bodemeenheden ter hoogte van de 40 meetlocaties in de Provincie Drenthe (Bodemkaart van Nederland, schaal 1 : 50 000).

\begin{tabular}{|c|c|c|c|c|c|}
\hline Profiel-nr. & Aantal locaties & Gt-klasse & \multicolumn{2}{|c|}{ organische stof $(\%)$} & Bodemeenheid \\
\hline 1 & 2 & Vb, VI & 1.7 & 0.6 & $\mathrm{Zn} 21$ \\
\hline 3 & 3 & VII & 5.2 & 3.9 & zEZ21, zEZ23 \\
\hline 4 & 29 & V, Vb, VI, VII, VIII & 5.2 & 2.2 & $\begin{array}{l}\mathrm{Hn} 21, \mathrm{Hn} 23, \mathrm{cH} 21, \mathrm{cH} 23, \mathrm{Hd} 21, \mathrm{cY} 21 \text {, } \\
\mathrm{cY} 23\end{array}$ \\
\hline 5 & 1 & IV, IIIb & 29.9 & 14.1 & $v W p, i W p, v W z, i W z$ \\
\hline 6 & 4 & III, IIIb & 34.6 & 64.0 & $\mathrm{aVz}, \mathrm{iVc}, \mathrm{iVz}$ \\
\hline totaal & 40 & & & & \\
\hline
\end{tabular}

\subsection{Gebruik}

De lijst van 31 stoffen die zijn geanalyseerd in de monsters van het grondwater van de Provincies Drenthe, Friesland, Groningen en Overijssel bevat 21 werkzame stoffen en 3 metabolieten van gewasbeschermingsmiddelen die zijn opgenomen in de database van de Nationale Milieu Indicator/NMI 2. Onder de resterende stoffen zijn een aantal niet (meer) toegelaten gewasbeschermingsmiddelen; zoals de herbiciden fenuron (geen gegevens bekend; Ctgb) en dichloorprop-p (geen toelating sinds november 1999) en het grondontsmettingsmiddel 1,3-dichloorpropeen. Verder staan er op deze lijst een aantal (chloor)verbindingen en de stof diethyltoluamide/DEET (bestanddeel van muggenolie).

Een deel van de lijst met geanalyseerde stoffen betreft werkzame stoffen die in het verleden (ook) buiten de landbouw werden toegepast. In een overzicht van het landsdekkend gemiddeld verbruik in de sector openbaar groen (gegevens 1986) staan de werkzame stoffen atrazin, bromacil, dichlobenil, 
diuron, glyfosaat, MCPA, mecoprop-P, en simazin vermeld. In het overzicht per 2001 staan de stoffen dichlobenil, glyfosaat, MCPA, mecoprop-P en simazin vermeld (Evaluatie Convenant Openbaar Groen; EC-LNV, 2003). In Bijlage 3 is een overzicht van de toepassingen in de landbouw en daar buiten gegeven, voor de 21 gewasbeschermingsmiddelen die zijn opgenomen in de database van de Nationale Milieu Indicator/NMI 2.

Van de 24 geanalyseerde gewasbeschermingsmiddelen zijn er 14 niet (meer) toegelaten op de Nederlandse markt. Veel stoffen hebben een toepassing (gehad) in een aantal grote teelten binnen de akkerbouw, de veehouderij en soms ook in een aantal andere landbouwsectoren. Er staan 8 werkzame stoffen op deze lijst die ook buiten de landbouw zijn toegepast. Door de breedte van deze toepassingen zijn de mogelijkheden om het voorkomen van een stof in het grondwater in verband te brengen met een specifieke toepassing beperkt.

\subsection{Stofeigenschappen}

Voor de uitspoelingsberekeningen van 21 werkzame stoffen en 3 metabolieten zijn stofgegevens uit de database NMI 2 gebruikt. Deze database bevat de geometrisch gemiddelde waarden voor de afbraaksnelheid en de rekenkundig gemiddelde waarden voor de sorptieparameters en de overige fysisch-chemische parameters (Bijlage 4).

\subsection{Uitspoeling van stoffen}

Om het uitspoelingsrisico voor de geanalyseerde stoffen en voor de verschillende locaties te kunnen rangschikken zijn berekeningen uitgevoerd met het model GeoPEARL 3.3.3. Dit model wordt gebruikt in de beoordeling van toelatingsaanvragen op het onderdeel uitspoeling. De doelgrootheid is het ruimtelijk 90-percentiel van de langjarig gemiddelde uitspoelingsconcentratie op $1 \mathrm{~m}$ diepte, berekend voor het gebruiksareaal in de Nederlandse landbouw. Het criterium is $0,1 \mu \mathrm{g} / \mathrm{L}$ voor het gebruiksareaal. Voor grondwaterbeschermingsgebieden geldt een veiligheidsfactor 10; stoffen met een ruimtelijk 90-percentiel voor het gebruiksareaal $>0,01 \mu \mathrm{g} / \mathrm{L}$ mogen niet binnen deze gebieden gebruikt worden. GeoPEARL maakt gebruik van een schematisatie van Nederland die is opgebouwd uit unieke combinaties van meteorologie, bodem, hydrologie en bodemgebruik (Tiktak et al., 2003; Tiktak et al., 2004). In de voorliggende studie zijn onderdelen van deze schematisatie gebruikt als invoergegevens voor regionale - en lokale berekeningen.

\subsubsection{Regionale berekeningen}

Om een uitspraak te kunnen doen over de kwetsbaarheid van het grondwater in de Provincie Drenthe als geheel, zijn landsdekkende berekeningen vergeleken met regionale berekeningen voor de Provincie Drenthe. Deze vergelijkingsmethode heeft betrekking op het ruimtelijk 90 -percentiel van de langjarig gemiddelde uitspoelingsconcentratie, en is eerder gebruikt om bijvoorbeeld de kwetsbaarheid van de drinkwatergebieden in Nederland te bepalen ten opzichte van de Nederlandse landbouw als geheel (Kruijne et al., 2003).

De landsdekkende schematisatie in GeoPEARL bestaat uit 6405 ruimtelijke eenheden, waarvan er 1334 voorkomen binnen de Provincie Drenthe. Conform de procedure beschreven in (Tiktak et al., 2004) zijn berekeningen uitgevoerd voor de werkzame stoffen en metabolieten uit de lijst van geanalyseerde stoffen die tevens zijn opgenomen in de database NMI 2 . In het model is een jaarlijkse toediening op 15 mei met een bodemdepositie van $1 \mathrm{~kg} \mathrm{ha}{ }^{-1}$ gehanteerd. Alleen voor isoproturon, dat voornamelijk werd toegepast in de teelt van wintertarwe, is het toedieningstijdstip 1 november gekozen.

De berekeningen kunnen worden gedaan voor specifieke gewassen of voor combinaties van gewassen. Vanwege de breedte van de toepassingen binnen de landbouw en daar buiten is ervoor gekozen om het ruimtelijk 90-percentiel van de langjarig gemiddelde uitspoelingsconcentratie te berekenen voor 
het grootst mogelijke gebruiksareaal; in GeoPEARL aangeduid als het ruraal (niet-stedelijk) gebied. Dit houdt in dat in deze berekeningen geen onderscheid wordt gemaakt naar het grondgebruik binnen het rurale gebied.

\subsubsection{Lokale berekeningen}

Om inzicht te krijgen in de relatieve kwetsbaarheid van het grondwater op de meetlocaties is voor de bodem-Gt-combinaties in Tabel 2 de langjarig gemiddelde concentratie berekend voor dezelfde stoffen als in de regionale berekeningen. Binnen de Provincie Drenthe zijn meerdere ruimtelijke eenheden met dezelfde bodem-Gt-combinaties aanwezig. Voor elke combinatie is de ruimtelijke eenheid met het grootste oppervlak geselecteerd. Het organischestofprofiel van deze ruimtelijke eenheid uit GeoPEARL is vervangen door het lokale organischestofprofiel volgens de Bodemkaart van Nederland (Sectie 2.2.2).

In Tabel 3 zijn enkele hydrologische kenmerken van de 4 geselecteerde ruimtelijke eenheden gegeven; de berekende langjarige gemiddelde hoeveelheid water die op $1 \mathrm{~m}$-mv uit de bouwvoor stroomt (hier de grondwateraanvulling genoemd) en het berekend grondwaterregime (Gt, GHG en GLG). Uit deze tabel valt af te lezen dat de grondwateraanvulling en daarmee ook het uitspoelingsrisico voor wat betreft de hydrologie op de ruimtelijke eenheid met grondwatertrap VII het grootst is. Deze ruimtelijke eenheid wordt als bodem-Gt-combinaties 3 en 4 gekoppeld aan 32 bemonsteringslocaties op zandgronden.

Tabel 3 Enkele hydrologische kenmerken van de ruimtelijke eenheden van de schematisatie in GeoPEARL die zijn geselecteerd voor lokale uitspoelingsberekeningen (Grondwatertrap/Gt, Gemiddelde Hoogste Grondwaterstand/GHG en Gemiddelde Laagste Grondwaterstand/GLG).

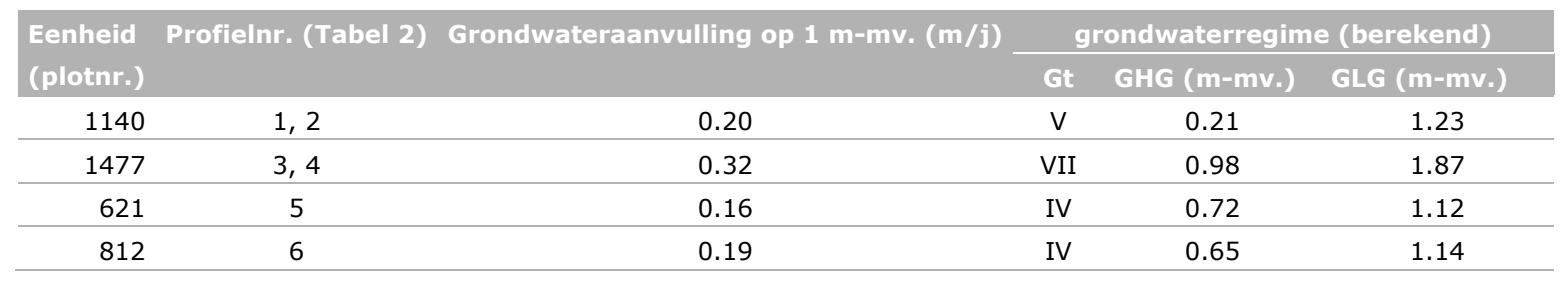

De resultaten van de lokale berekeningen zijn in de vorm van de langjarig gemiddelde uitspoelingsconcentraties voor 24 stoffen en 6 bodem-Gt-combinaties opgenomen in Tabel 5. De berekende uitspoelingskaarten van bentazon zijn als voorbeeld opgenomen in Bijlage 5 . 


\section{$3 \quad$ Resultaten en discussie}

Vergeleken met werkzame stoffen en metabolieten van gewasbeschermingsmiddelen in het oppervlaktewater zijn er bij een herkomstanalyse van stoffen in het grondwater een aantal extra bronnen van onzekerheid om rekening mee te houden. Zo is er geen directe relatie tussen de aanwezigheid in het grondwater en het tijdstip van gebruik, omdat afhankelijk van de filterdiepte van de bemonsteringsbuis de reistijd van het grondwater van de bouwvoor naar filterdiepte zo'n 10 jaar of meer kan bedragen. De hoeveelheid uitspoeling uit de bovenste meter van de bodem verschilt van jaar tot jaar, afhankelijk van de weerscondities. Verder geldt dat voor maar weinig stoffen iets bekend is over de afbraak in de ondergrond (vanaf $1 \mathrm{~m}$ beneden maaiveld tot aan de diepte van het filter). In de meeste gevallen zijn de vorm en de omvang van het gebied, waar het water dat uit de bouwvoor percoleert het filter van de bemonsteringsbuis kan bereiken, niet bekend.

Een en ander heeft tot gevolg dat een analyse van de mogelijke herkomst van stoffen in het grondwater anders van opzet is dan bij stoffen die in het oppervlaktewater zijn gemeten. In de volgende paragrafen worden de monitoringsresultaten vergeleken met de verzamelde locatiegegevens en met de resultaten van de modelberekeningen. Voor de stof bentazon worden de resultaten van regionale - en lokale uitspoelingsberekeningen besproken in Sectie 3.3.

\subsection{Monitoring}

Op 20 locaties in de Provincie Drenthe zijn een of meerdere stoffen aangetoond. In de 20 overige locaties zijn geen stoffen aangetoond. In Figuur 1 zijn de locaties gegeven inclusief het aantal metingen als percentage van het aantal analyses per locatie. Het grootste aantal stoffen dat op één locatie is aangetoond bedraagt 6 (putnr. 115; zie Bijlage 1, Tabel 1-6).

De meeste stoffen zijn aangetoond in het grondwater ter hoogte van het ondiepe filter. Dit geldt ook voor het percentage van het aantal analyses per filter. Deze bevinding komt overeen met de resultaten van de landelijke nulmeting in 2006 (Van der Linden et al., 2007). Het komt zowel voor dat de maximum gemeten concentratie van een stof in de diepe filters hoger is dan de maximum gemeten concentratie in de ondiepe filters, als andersom.

Als het grondwater in het ondiepe filter op een recenter tijdstip is geïnfiltreerd dan het grondwater in het diepe filter, dan kan de concentratie van een stof als gevolg van afbraak afnemen met de diepte. Er zijn echter stoffen waarvoor geldt dat de intensiteit van het gebruik in de loop der jaren is gedaald, als gevolg van een aanpassing van de aanbevolen dosering of andere wijzigingen in de toelating. Het verloop van de concentratie met de diepte kan ook het gevolg zijn van variatie in de jaarlijkse weersomstandigheden. Verder geldt dat een gemeten concentratie op een bepaalde diepte en een bepaald tijdstip niets zegt over de vorm en de omvang van de verontreiniging, die zich in alle richtingen in het grondwatersysteem uitstrekt en zich bovendien langzaam verplaatst en/of verder verspreidt. De concentratie in een dergelijke pluimvormige verontreiniging kan door enige verdunning afnemen in de tijd.

Om deze redenen is niet mogelijk om zonder uitvoerig onderzoek op een specifieke locatie een eenduidige oorzaak voor de aanwezigheid van een stof in het (diepe) grondwater aan te wijzen. Wel is het zinvol om na te gaan wat de overeenkomsten zijn van locaties waar stoffen zijn aangetoond, en van de locaties waar deze stoffen niet zijn aangetoond. 


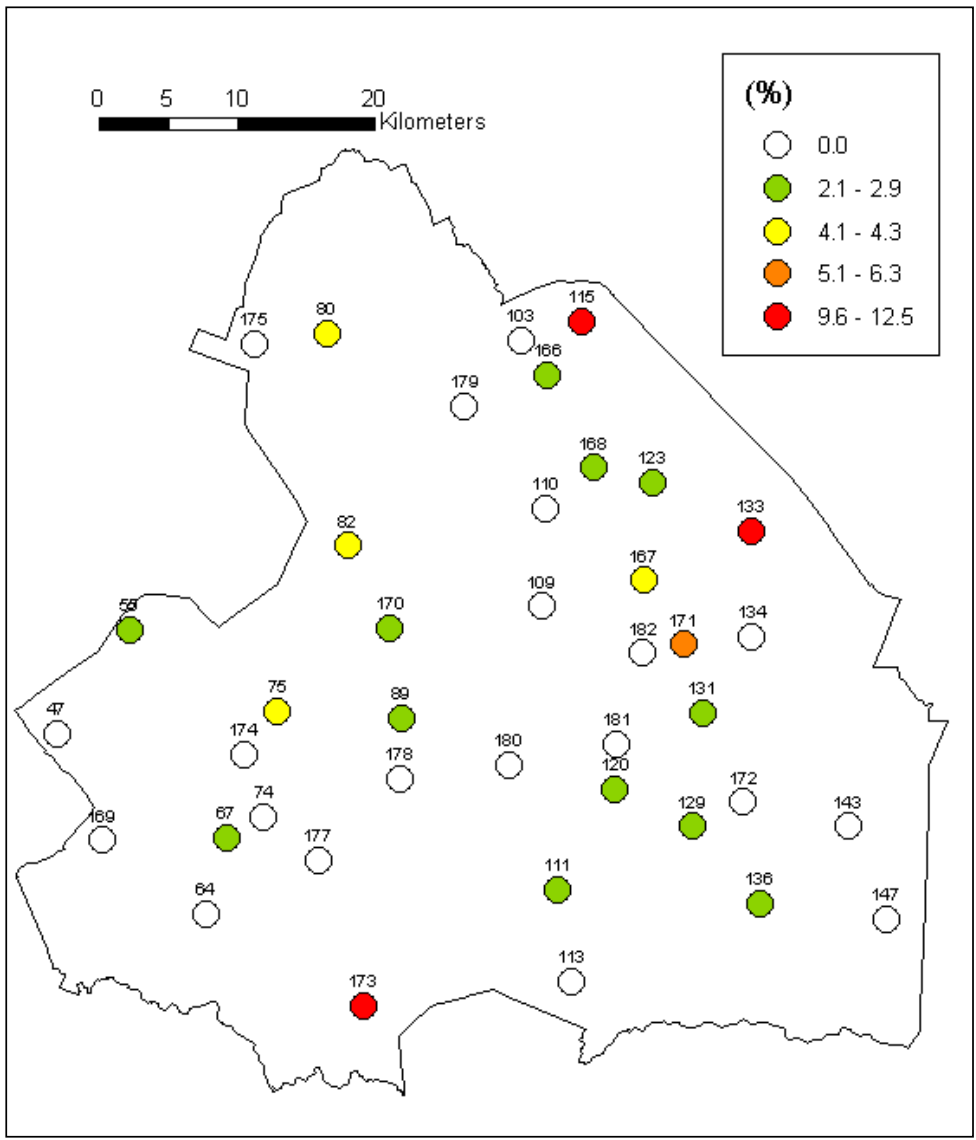

Figuur 1 Het aantal metingen per locatie (in \% van het aantal analyses per locatie). De labels geven de locatienummers die in dit rapport zijn gebruikt.

De stof ethofumesaat (5 keer aangetoond in Drenthe, Tabel 1) wordt vooral in de teelt van suikerbieten gebruikt, en daarnaast in veel mindere mate in de teelt van graszaad. De stof metalaxyl (3 keer aangetoond in Drenthe, Tabel 1) daarentegen is veel breder toegepast in meerdere teelten binnen de akkerbouw, vollegronds groenteteelt, bloembollen en boomkwekerij. Voor de stoffen dichlobenil en glyfosaat geldt dat met name de risico's van het gebruik buiten de landbouw aandacht verdient.

Op dit moment is de Werkgroep Validatie Beslisboom Uitspoeling (Alterra-RIVM-PBL-VEWIN-Ctgb) actief. Deze werkgroep toetst of de huidige beslisboom uitspoeling het grondwater in Nederland voldoende beschermt. Deze werkgroep heeft een selectie van stoffen gemaakt mede op basis van de metingen in grondwaterwinningen en in de Provinciale Meetnetten Grondwaterkwaliteit. In de rapportage van deze werkgroep wordt uitvoerig ingegaan op de stoffen bentazon, MCPA, en mecoprop-p. De stoffen bentazon en mecoprop-p zijn onder andere in de Provincie Drenthe aangetoond (Tabel 1). De rapportage van deze werkgroep zal naar verwachting in 2009 openbaar zijn.

In 2006 en 2007 zijn in de Provincie Drenthe vrijwel dezelfde stoffen aangetoond. Bovendien zijn de meeste stoffen in de afgelopen jaren ook elders in Nederland in het grondwater aangetroffen. Het grootste deel van de stoffen die in Drenthe en/of in de andere Noordelijke provincies zijn aangetroffen is medio 2008 niet meer toegelaten. Er zijn 18 werkzame stoffen en metabolieten aangetoond in het grondwater van Groningen, Friesland en/of Overijssel, die niet zijn aangetroffen in de Provincie Drenthe (Tabel 4). 
Tabel 4 Stoffen aangetoond in het grondwater van Groningen, Friesland en/of Overijssel, die niet zijn aangetoond in de Provincie Drenthe (monitoringsresultaten 2006, 2007).

\begin{tabular}{|c|c|c|}
\hline Stofnaam & Aantal aangetoond & Toelating (medio 2008) \\
\hline desethyl-atrazin & 1 & (zie atrazin) \\
\hline dimethenamide & 1 & $N^{1}$ \\
\hline metazachloor & 1 & $\mathrm{~J}$ \\
\hline triadimefon & 1 & $\mathrm{~N}$ \\
\hline bromacil & 2 & $\mathrm{~N}$ \\
\hline carbeetamide & 2 & J \\
\hline glyfosaat & 2 & J \\
\hline simazin & 2 & $\mathrm{~N}$ \\
\hline isoproturon & 3 & $\mathrm{~J}^{3}$ \\
\hline MCPA & 3 & J \\
\hline monolinuron & 3 & $\mathrm{~N}$ \\
\hline dichloorprop-p & 5 & $\mathrm{~N}$ \\
\hline aminomethylfosfonzuur (AMPA) & 8 & (zie glyfosaat) \\
\hline
\end{tabular}

Voor de stof AMPA (metaboliet van glyfosaat) geldt een niet-relevantverklaring. De stof carbeetamide ( 2 keer aangetoond buiten Drenthe) wordt minder intensief gebruikt en kent geen brede toepassing in grote teelten (Bijlage 4). Het herbicide carbeetamide wordt vooral toegepast in de vollegronds groenteteelt (witlof, schorseneren), de akkerbouw (cichorei) en de boomkwekerij (sierconiferen). Hetzelfde geldt in mindere mate voor het herbicide metazachloor ( 1 keer aangetoond buiten Drenthe), dat wordt toegepast in de vollegronds groenteteelt, de akkerbouw, de fruitteelt en de boomkwekerij (sierconiferen). Wellicht is het mogelijk om het voorkomen van deze stoffen in verband te brengen met een bepaalde toepassing.

\subsection{Locatiegegevens}

In 1992 zijn er 2 locaties (putnr. 55 en 109) met uitsluitend bos- en natuur in de directe omgeving. In 2004 zijn daar nog 2 locaties bijgekomen. In een van deze locaties (putnr. 55) is de stof diuron gemeten. Diuron werd in de landbouw gebruikt, maar ook als onkruidbestrijdingsmiddel op spoorbanen en verhardingen, en als aangroeiwerend middel op scheepshuiden. Diuron wordt ook op veel plaatsen in het oppervlaktewater aangetroffen.

In alle overige locaties zijn zowel de akkerbouw (aardappelen, bieten, granen) als de veeteelt (grasland, mais) aanwezig in dezelfde opname van het grondgebruik, dan wel in afwisseling. De LGNklasse "overige landbouwgewassen" komt vaak in combinatie met de akkerbouw voor. In deze klasse zijn zowel de akkerbouw (kleine gewassen) als een aantal andere sectoren vertegenwoordigd (boomkwekerij, vollegronds groenteteelt). In 2004 is de bollenteelt aanwezig in de directe omgeving van 2 locaties. In 2/3 deel van de locaties komt bebouwd gebied voor. Uit deze beschrijving blijkt dat er geen eenduidig onderscheid is tussen locaties op bouwland en locaties op grasland. In de meeste locaties met landbouwkundig grondgebruik moet bovendien rekening gehouden worden met de risico's volgend uit een niet-landbouwkundige vorm van gebruik.

Het grondgebruik volgens de opnames van 4 achtereenvolgende versies van het LGN en de classificatie van het bodemgebruik volgens de locatiegegevens van het meetnet leveren hetzelfde beeld op. Het feit dat er op basis van de beschikbare gegevens weinig onderscheid is tussen de 
landbouwkundige vormen van grondgebruik betekent dat er op specifieke locaties geen toepassingen uitgesloten kunnen worden.

In de meeste gevallen zijn de monsters afkomstig uit filters waar de ouderdom van het grondwater aan de hand van het tritiumgehalte in 1994 werd bepaald als recent (d.w.z. water dat na 1950 is geïnfiltreerd) of als mengwater (van recent en niet-recent geïnfiltreerd water). Op één uitzondering na zijn de gemeten stoffen afkomstig uit filters met recent geïnfiltreerd water. Deze uitzondering is een herhaalde meting in 2006 en 2007 in het diepe filter van putnr. 89 (0,01 $\mu \mathrm{g} / \mathrm{L}$ diuron = detectielimiet). In de overige 5 filters met niet-recent geïnfiltreerd water zijn geen stoffen gemeten.

Op grond van het bovenstaande wordt geconcludeerd dat op basis van deze locatiekenmerken de mogelijkheden om tot een verdere optimalisatie van de monitoring van het grondwater te komen zeer beperkt zijn.

\subsection{Berekeningen}

De belangrijkste resultaten van de berekeningen zijn opgenomen in Bijlage 5, inclusief enkele kaarten met bodemeigenschappen en een illustratie van de regionale berekeningen voor de stof bentazon.

\subsubsection{Regionaal}

In Figuur 2 is het uitspoelingsrisico in Nederland en Drenthe vergeleken voor de 24 werkzame stoffen en metabolieten van gewasbeschermingsmiddelen die in de database NMI 2 zijn opgenomen, op basis van het ruimtelijk 90-percentiel van de langjarig gemiddelde uitspoelingsconcentratie op $1 \mathrm{~m}$ diepte. Op de horizontale as is de concentratie voor Nederland uitgezet op logaritmische schaal. Op de verticale as is de concentratie voor de Provincie Drenthe uitgezet op logaritmische schaal. Deze concentraties zijn berekend bij een nominale bodemdepositie $=1 \mathrm{~kg} / \mathrm{ha}$ (Sectie 2.5 ).

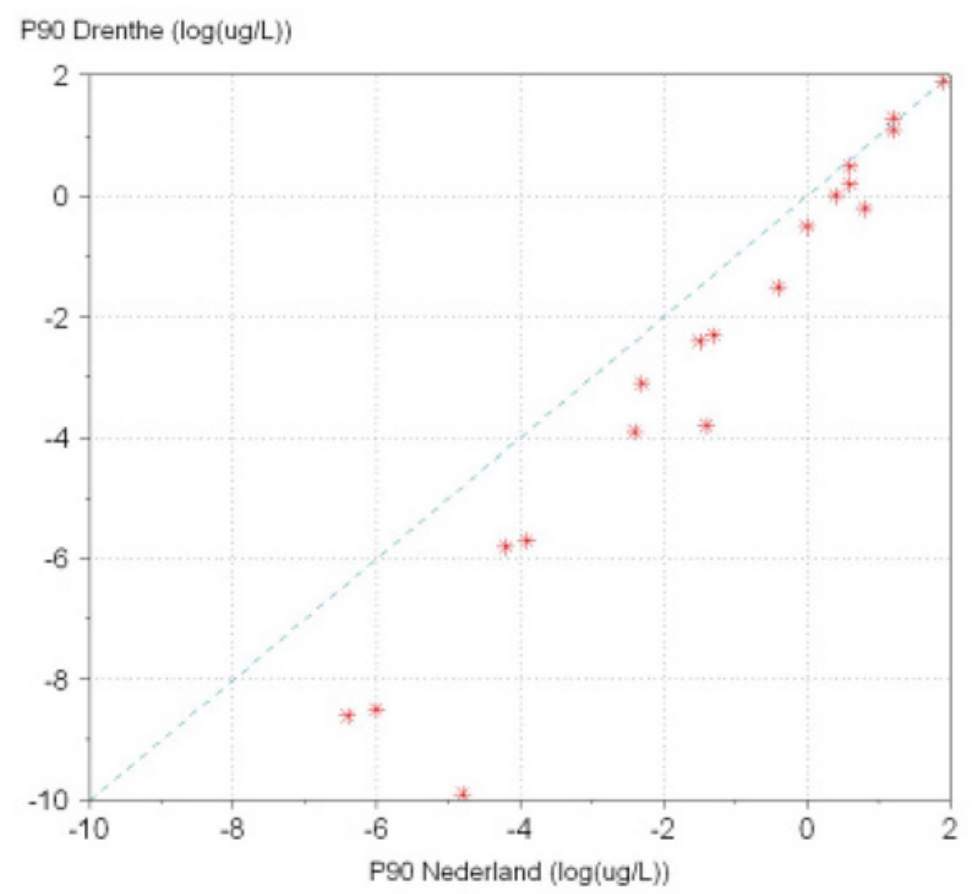

Figuur 2 Het uitspoelingsrisico in Nederland en Drenthe vergeleken voor 21 werkzame stoffen en 3 metabolieten (ruimtelijk 90-percentiel van de langjarig gemiddelde uitspoelingsconcentratie op $1 \mathrm{~m}$ in $\mu \mathrm{g} / \mathrm{L}$, bij een nominale bodemdepositie $=1 \mathrm{~kg} / \mathrm{ha}$ ). 
Voor bentazon bijvoorbeeld is het ruimtelijk 90-percentiel van de uitspoelingsconcentratie in Nederland als geheel $=16 \mu \mathrm{g} / \mathrm{L}$ en in de Provincie Drenthe $=12 \mu \mathrm{g} / \mathrm{L}$. Dit betekent voor de Provincie Drenthe, dat in $90 \%$ van het ruraal (niet-stedelijk) gebied een uitspoelingsconcentratie $<12 \mu \mathrm{g} / \mathrm{L}$ is berekend, en in de overige 10\% van het ruraal (niet-stedelijk) gebied een uitspoelingsconcentratie $\geq 12 \mu \mathrm{g} / \mathrm{L}$. Voor vrijwel alle stoffen (behalve bromacil en BAM) is het 90-percentiel van de uitspoelingsconcentratie op 1-m diepte in Nederland hoger dan in de Provincie Drenthe. Deze concentraties zijn berekend met stofgegevens uit de NMI-database (Bijlage 4). De juistheid van deze gegevens wordt momenteel voor een aantal stoffen onderzocht door de Werkgroep Validatie Beslisboom Uitspoeling

Uit deze regionale berekeningen blijkt dat het grondwater in de Provincie Drenthe als geheel minder kwetsbaar is voor uitspoeling van stoffen dan het grondwater in Nederland. Dit wordt verklaard door de aanwezigheid van moerige gronden en veengronden in de Provincie Drenthe. Voor stoffen met $\mathrm{pH}$ afhankelijke sorptie wordt dit effect versterkt door de afwezigheid van grote gebieden met een hoge $\mathrm{pH}$ in de bodem. Bij een hoge $\mathrm{pH}$ in de bodem zijn deze stoffen mobieler en spoelen daardoor gemakkelijker uit dan bij een lage pH in de bodem. Dit geldt voor de stoffen bentazon, carbeetamide, carbendazim, glyfosaat, MCPA en mecoprop-p.

\subsubsection{Lokaal}

De resultaten van de berekeningen met lokale invoergegevens geven een beeld van de gevoeligheid van het uitspoelingsrisico voor het gehalte organische stof in de bodem en voor de hydrologische omstandigheden op de bemonsteringslocaties.

Uit Tabel 5 valt af te leiden dat de range voor de hier gehanteerde maat voor het lokale uitspoelingsrisico op de 6 profielnummers (combinaties van organische stof en hydrologie; Tabel 2) voor sommige stoffen tot een factor $10^{7}$ kan oplopen. De belangrijkste oorzaak is de variatie in het gehalte organische stof (van 1,7\% voor profielnr. 1, tot 34,6\% voor profielnr. 6; Tabel 2).

Om een indruk te krijgen van de representativiteit van deze locaties voor wat betreft het uitspoelingsrisico voor het grondwater in de Provincie Drenthe als geheel, zijn de concentraties bentazon op deze 6 typen locaties uitgezet in de grafiek met de cumulatieve frequentie van de uitspoelingsconcentratie (Figuur 3). Uit deze figuur en uit het overzicht in Tabel 2 blijkt dat de combinaties van organische stof en hydrologie met het grootste uitspoelingsrisico zijn oververtegenwoordigd in de bemonstering; er zijn 19 locaties met profielnummer 4. De uitspoelingsconcentratie van een mobiele stof als bentazon wordt mede bepaald door de aanvulling van het grondwater vanuit de bouwvoor. Deze hoeveelheid water is voor profielnummers 3 en 4 het grootst (Tabel 3). De stof bentazon is gemeten op 7 locaties met profielnummer 4, op 1 locatie met profielnummer 3, en op 1 locatie met profielnummer 6. Voor details zie Bijlage 1, Tabel 1.7.

Voor bentazon is er een duidelijke relatie tussen de berekende uitspoelingsgevoeligheid en de locaties waar deze stof is gemeten. Deze relatie is mede afhankelijk van de stofeigenschappen en zal per stof verschillend zijn. Aanbevolen wordt om ook voor andere stoffen de representativiteit van de bemonsteringslocaties voor het grondwater in de Provincie Drenthe qua uitspoelingsgevoeligheid in beeld te brengen. 
Tabel 5 Het lokale uitspoelingsrisico op 6 typen locaties (het langjarig gemiddelde van de lokale uitspoelingsconcentratie, berekend bij een nominale bodemdepositie; in $\mu \mathrm{g} / \mathrm{L}$ ). De notatie van de concentraties in deze tabel zijn aangepast omwille van de leesbaarheid.

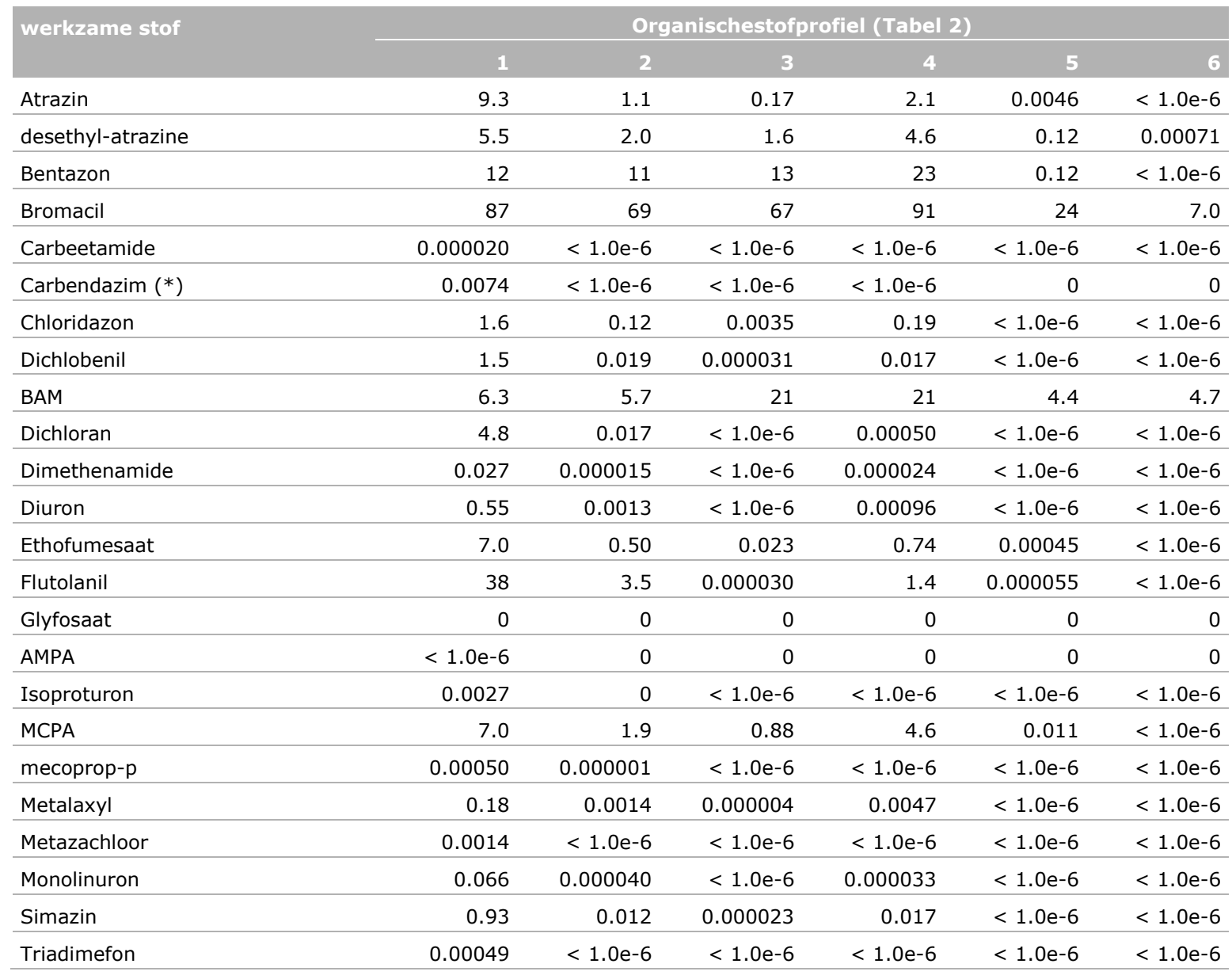

${ }^{*}$ ) De waarde van $\mathrm{K}_{\mathrm{om} \text {,base }}$ voor carbendazim is onjuist. Er geldt $>150 \mathrm{~L} / \mathrm{kg}$. Berekening met de juiste waarde leidt tot een lagere uitspoelingsconcentratie voor deze stof.

Gegeven deze onzekerheid is het zinvol om nadere informatie te verzamelen en na te gaan of er specifieke omstandigheden zijn die hebben geleid tot het aantreffen van de stoffen. Locaties waar meerdere stoffen tegelijkertijd zijn aangetroffen komen hiervoor het eerste in aanmerking. Deze mogelijkheden zijn nader besproken in (Van der Linden et al., 2007). 


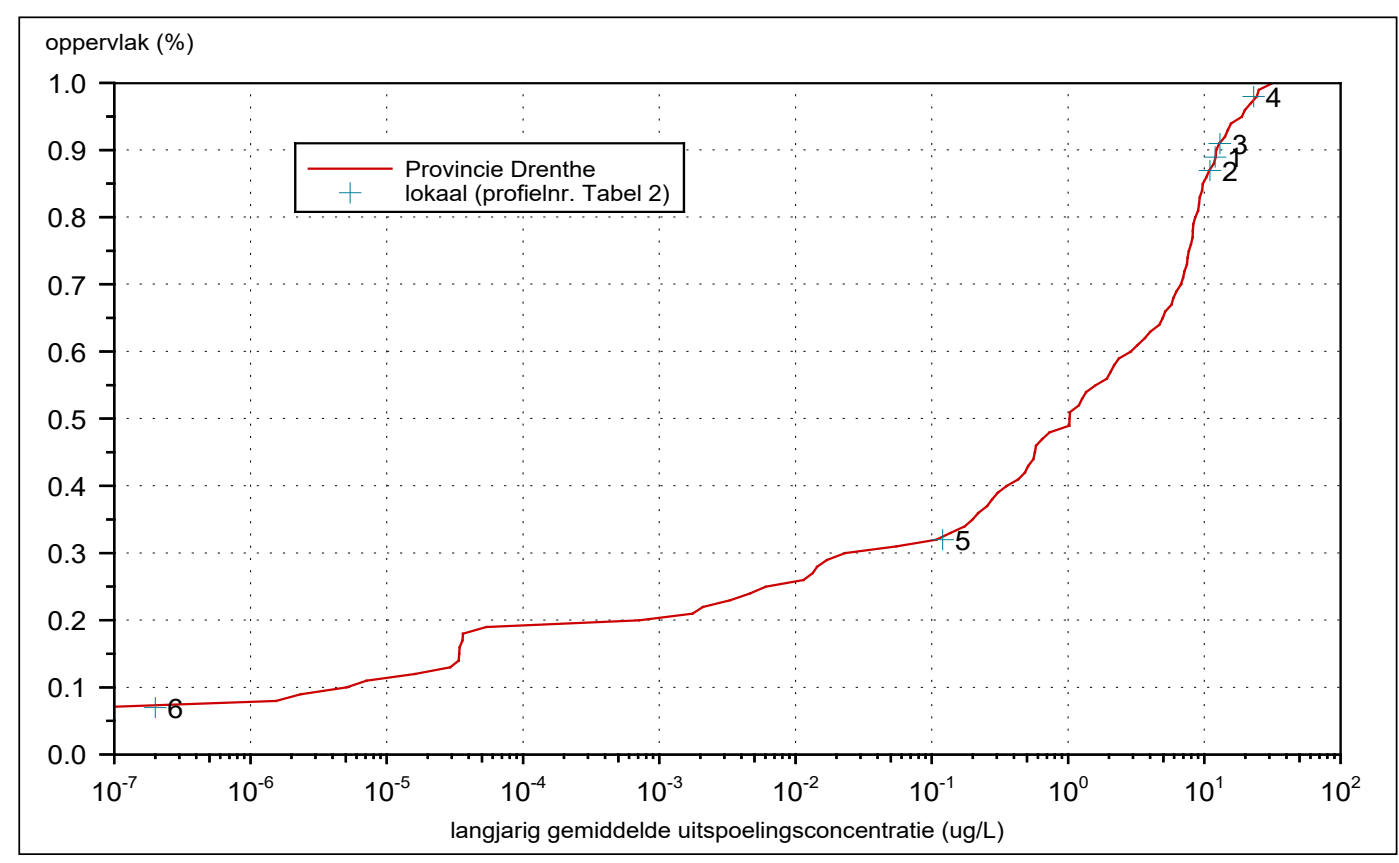

Figuur 3 De cumulatieve frequentie van de uitspoelingsconcentratie bentazon, berekend voor het oppervlak van de Provincie Drenthe $(\mu \mathrm{g} / \mathrm{L})$. De uitspoelingsconcentratie berekend voor de bemonsteringslocaties is weergegeven voor profielnummer $1 \mathrm{t} / \mathrm{m} 6$ (deze vertegenwoordigen 2, 1, 3 29, 1, respectievelijk 4 bemonsteringslocaties; zie Tabel 2). 


\section{$4 \quad$ Conclusies en aanbevelingen}

Uit het overzicht van de meetgegevens van het grondwater in de Provincie Drenthe is geconcludeerd dat de resultaten van 2007 een bevestiging zijn van de resultaten uit 2006. Er zijn geen nieuwe inzichten uit de resultaten van de laatste ronde naar voren gekomen. Gezien de lengte van de filters ligt dit in de lijn der verwachtingen omdat gedeeltelijk hetzelfde water (afkomstig van dezelfde toepassingen) is bemonsterd.

De mogelijkheden om, op basis van locatiekenmerken die in de locatiegegevens van het meetnet zijn vastgelegd of die ter aanvulling uit landelijke gegevensbestanden zijn gehaald, een verdere optimalisatie van de monitoring van het grondwater te bereiken, zijn zeer beperkt.

Uit een vergelijking op basis van het ruimtelijk 90-percentiel van de langjarig gemiddelde uitspoelingsconcentratie op $1 \mathrm{~m}$ diepte blijkt dat voor de meeste geanalyseerde werkzame stoffen en metabolieten het uitspoelingsrisico voor het grondwater in de Provincie Drenthe lager is dan voor het grondwater in Nederland.

Voor bentazon is er een duidelijke relatie tussen de berekende uitspoelingsgevoeligheid en de locaties waar deze stof is gemeten. Deze relatie is mede afhankelijk van de stofeigenschappen en zal per stof verschillend zijn. Aanbevolen wordt om ook voor andere stoffen de representativiteit van de bemonsteringslocaties voor het grondwater in de Provincie Drenthe qua uitspoelingsgevoeligheid in beeld te brengen.

Het Provinciaal (en het Landelijk) Meetnet Grondwaterkwaliteit zijn in beginsel niet bedoeld voor jaarlijkse bemonstering. Gegeven de diepte en de lengte van de filters is het niet zinvol om vaker dan ééns per 2 jaar monsters te analyseren op gewasbeschermingsmiddelen. Om deze reden wordt aanbevolen om de komende 2-3 jaar geen bemonstering van het grondwater (PMG) op te zetten op dezelfde locaties. Eventueel, als er meer putten zijn, dan zou bemonstering daarvan wel overwogen kunnen worden.

Op dit moment is de Werkgroep Validatie Beslisboom Uitspoeling (Alterra-RIVM-PBL-VEWIN-Ctgb) actief. Deze werkgroep toetst of de huidige beslisboom uitspoeling het grondwater in Nederland voldoende beschermt. Voor wat betreft de stoffen bentazon en mecoprop-p wordt aanbevolen om de rapportage van de Werkgroep Validatie Beslisboom Uitspoeling en/of eventuele ontwikkelingen omtrent de toelating af te wachten.

Conform het landelijk beeld uit de nulmeting 2006, zijn de meeste stoffen in de Provincie Drenthe aangetoond in het water in de ondiepe filters van de meetlocaties. Over het algemeen zal dit water op een recenter tijdstip geïnfiltreerd zijn dan het grondwater in het diepe filter. Geadviseerd wordt om beter in te spelen op de ontwikkelingen in het agrarisch grondgebruik en de daarmee samenhangende veranderingen in het middelengebruik in de landbouw, door naar een bemonstering van het bovenste grondwater over te stappen. Zo kan beter het directe verband tussen gebruik en lokale omstandigheden in beeld worden gebracht

Aanbevolen wordt om in de opzet van een nieuwe monitoringsronde bij de keuze van het stoffenpakket rekening te houden met de resultaten van eerdere inventarisaties van het gebruik in de landbouw (Merkelbach et al., 2008) en daarbuiten (Spijker en Niemeijer, 2008), en met de resultaten van een analyse van de mogelijke herkomst van stoffen in de Provincie Drenthe en andere regio's.

Ongeveer 2/3 van de aangetoonde stoffen in de Provincie Drenthe en de overige Noordelijke provincies is medio 2008 niet meer toegelaten. Aanbevolen wordt om in volgende bemonsteringsronden minder analyses aan deze stoffen te besteden. 
Het is zinvol om na te gaan of er specifieke omstandigheden zijn die hebben geleid tot het aantreffen van stoffen. Locaties waar meerdere stoffen tegelijkertijd zijn aangetroffen komen hiervoor het eerste in aanmerking. 


\section{Literatuur}

EC-LNV, 2003. Evaluatie convenant openbaar groen - onderdeel emissies. In: Evaluatie bestuurlijke afspraken uitvoering MJP-G openbaar groen; achtergronddocument. Ede, EC-LNV/183 - p. 51-85.

Kruijne, R.; Smelt, J.H. (2003) Selectie van locaties en bestrijdingsmiddelen voor monitoring in het diepe grondwater. Wageningen : Alterra, (Alterra-rapport 761) - p. 57.

Kruijne, R.; Tiktak, A.; Kraalingen, D.W.G. van; Boesten, J.J.T.I.; Linden, A.M.A. van der (2004) Pesticide leaching to the groundwater in drinking water abstraction areas; analysis with the GeoPEARL model. Alterra. (Alterra-rapport 1041) - p. 66.

Linden, A.M.A. van der; Boesten, J.J.T.I.; Cornelese, A.A.; Kruijne, R.; Leistra, M.; Linders, J.B.H.J.; Pol, J.W.; Tiktak, A.; Verschoor, A.J. (2004) The new decision tree for the evaluation of pesticide leaching from soils. Bilthoven, RIVM Report 601450019 - p. 57.

Merkelbach, R.C.M., R. Kruijne, J.G. Groenwold, C.M. Niemeijer en J.H. Spijker, 2008. Gewasbeschermingsmiddelen in Drenthe - Een verkenning 2006-2007. Alterra, Wageningen UR.

Spijker, J.H. en C.M. Niemeijer, 2008. Gewasbeschermingsmiddelen in Drenthe; Fase 2b; Inventarisatie van het niet-landbouwkundig gebruik van gewasbeschermingsmiddelen in de provincie Drenthe. Alterra, Wageningen UR.

Tiktak, A., A.M.A. van der Linden en J.J.T.I. Boesten, 2003. The GeoPEARL model. description, applications and manual. Bilthoven, RIVM, report 716601007.

Tiktak, A., A.M.A. van der Linden, J.J.T.I. Boesten, R. Kruijne en D. van Kraalingen, 2004. The GeoPEARL model. Part II. User guide and model description update. Bilthoven, RIVM, report 716601008.

Van der Linden, A.M.A., H.F.R. Rijnders, M.C. Zijp en A.M. Durand-Huiting, 2007. Residuen van gewasbeschermingsmiddelen in het grondwater. Een analyse voor de KRW. RIVM rapport $607310001 / 2007$ (Concept)

Van der Linden, A.M.A., J.G. Groenwold, R. Kruijne, R. Luttik, and R.C.M. Merkelbach, 2008. Dutch Environmental Indicator for plant protection products, version 2. Input, calculation and aggregation procedures. Bilthoven, RIVM Report 607600002. 69 p. 


\section{Bijlage 1 Monitoringsresultaten grondwater Drenthe}

\section{Overzicht meetgegevens}

Tabel 1-1 Het aantal analyses.

\begin{tabular}{lrrr} 
jaar & aangetoond & niet aangetoond & totaal \\
\hline 2002 & 8 & 135 & 143 \\
\hline 2004 & 6 & 202 & 208 \\
\hline 2006 & 23 & 1033 & 1056 \\
\hline 2007 & 31 & 1139 & 1170 \\
\hline totaal & 68 & 2509 & 2577 \\
\hline
\end{tabular}

Tabel 1-2 Het aantal analyses per filter.

\begin{tabular}{lrrrrrr} 
& \multicolumn{4}{c}{ jaar } & \multicolumn{3}{c}{ totaal } \\
\cline { 2 - 7 } 1 & 2002 & 2004 & 2006 & 2007 & & $\%$ \\
\hline 2 & 110 & 160 & 528 & 546 & 1344 & 52 \\
\hline 3 & 33 & 16 & & 78 & 127 & 5 \\
\hline totaal & & 32 & 528 & 546 & 1106 & 43 \\
\hline
\end{tabular}

Tabel 1-3a Het aantal aangetoond per filter.

\begin{tabular}{|c|c|c|c|c|c|c|}
\hline \multirow[t]{2}{*}{ filter } & \multicolumn{3}{|c|}{ jaar } & \multicolumn{3}{|c|}{ totaal } \\
\hline & 2002 & 2004 & 2006 & 2007 & & $\%$ \\
\hline 1 & 6 & 5 & 16 & 19 & 46 & 68 \\
\hline 2 & 2 & & & & 2 & 3 \\
\hline 3 & & 1 & 7 & 12 & 20 & 29 \\
\hline totaal & 8 & 6 & 23 & 31 & 68 & 100 \\
\hline
\end{tabular}

Tabel 1-3b Het percentage aangetoond per filter.

\begin{tabular}{|c|c|c|c|c|c|}
\hline \multirow[t]{2}{*}{ filter } & \multicolumn{4}{|c|}{ jaar } & \multirow[t]{2}{*}{ totaal } \\
\hline & 2002 & 2004 & 2006 & 2007 & \\
\hline 1 & 5.5 & 3.1 & 3.0 & 3.5 & 3.4 \\
\hline 2 & 6.1 & 0.0 & & & 1.6 \\
\hline 3 & & 3.1 & 1.3 & 2.2 & 1.8 \\
\hline totaal & 5.6 & 2.9 & 2.2 & 2.6 & 2.6 \\
\hline
\end{tabular}


Tabel 1-4 Aantal analyses en het percentage aangetoond per locatie.

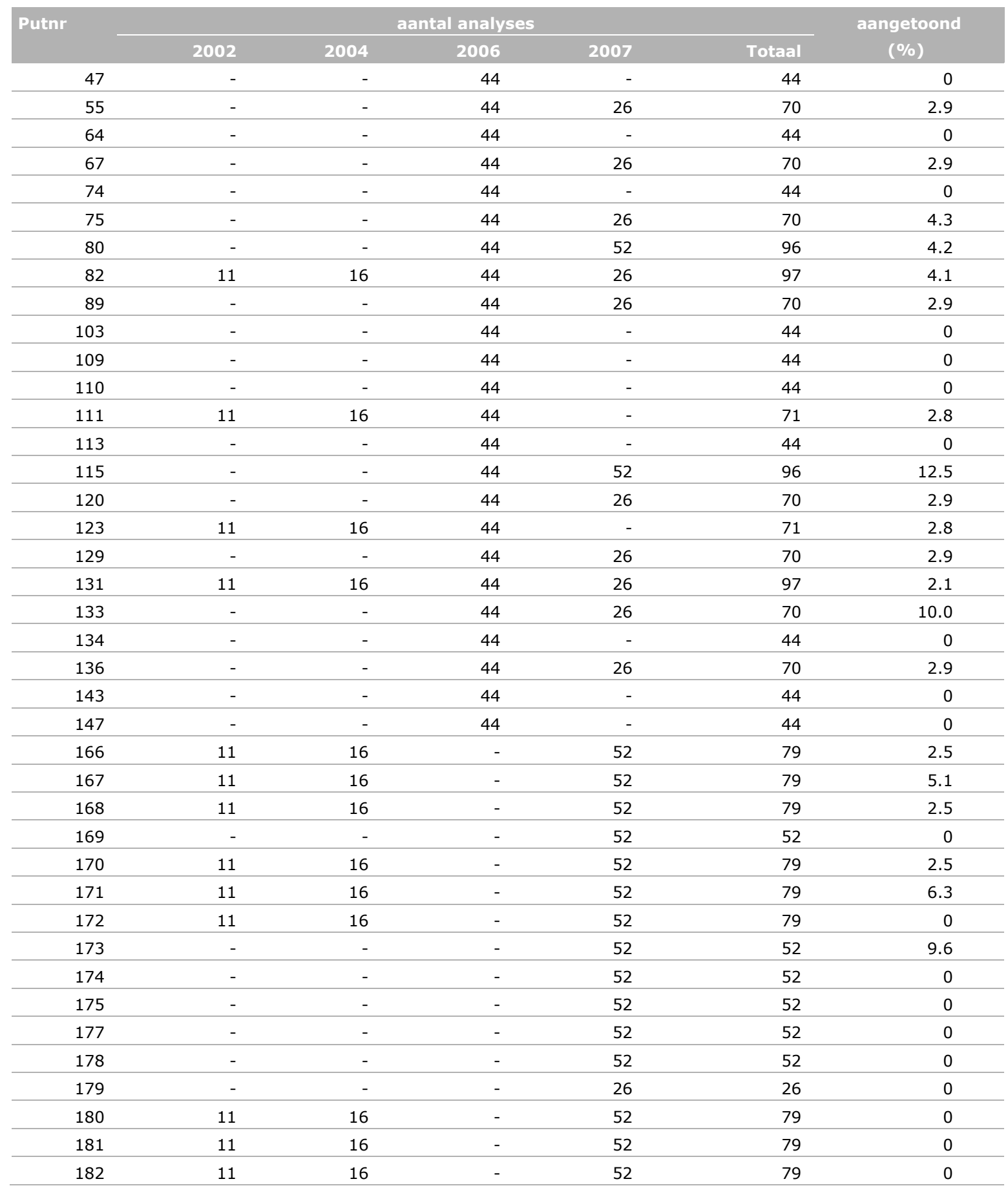


Tabel 1-5 Stofnummers in het overzicht met de metingen per locatie.

\begin{tabular}{|c|c|}
\hline 1 & atrazin \\
\hline 3 & bromacil \\
\hline 4 & carbeetamide \\
\hline 5 & carbendazim \\
\hline 6 & chloridazon \\
\hline 8 & dichloran \\
\hline 9 & dimethenamide \\
\hline 10 & diuron \\
\hline 11 & ethofumesaat \\
\hline 15 & MCPA \\
\hline 16 & mecoprop-p \\
\hline 17 & metalaxyl \\
\hline 18 & metazachloor \\
\hline 19 & monolinuron \\
\hline 20 & simazin \\
\hline 21 & triadimefon \\
\hline 22 & aminomethylphosphonic acid (AMPA) \\
\hline 29 & fenuron \\
\hline 30 & tetrachlooretheen \\
\hline 31 & trichlooretheen \\
\hline
\end{tabular}




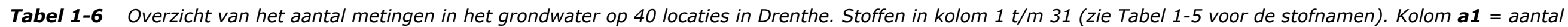
metingen per locatie, $\mathbf{a} \mathbf{2}$ = aantal stoffen per locatie. Regel $\mathbf{A 1}=$ totaal aantal metingen per stof $\mathbf{A 2}=$ totaal aantal locaties waar de stof is gemeten).

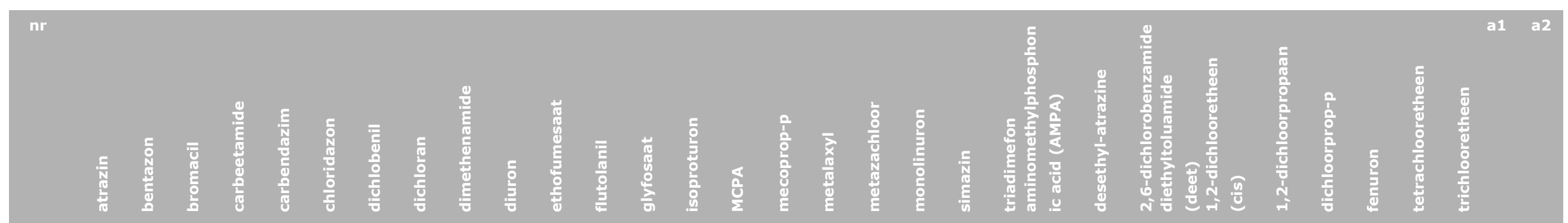

$$
47
$$

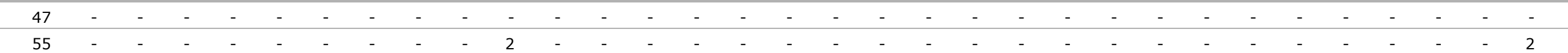

55

67

74

75

80

$82-$ 


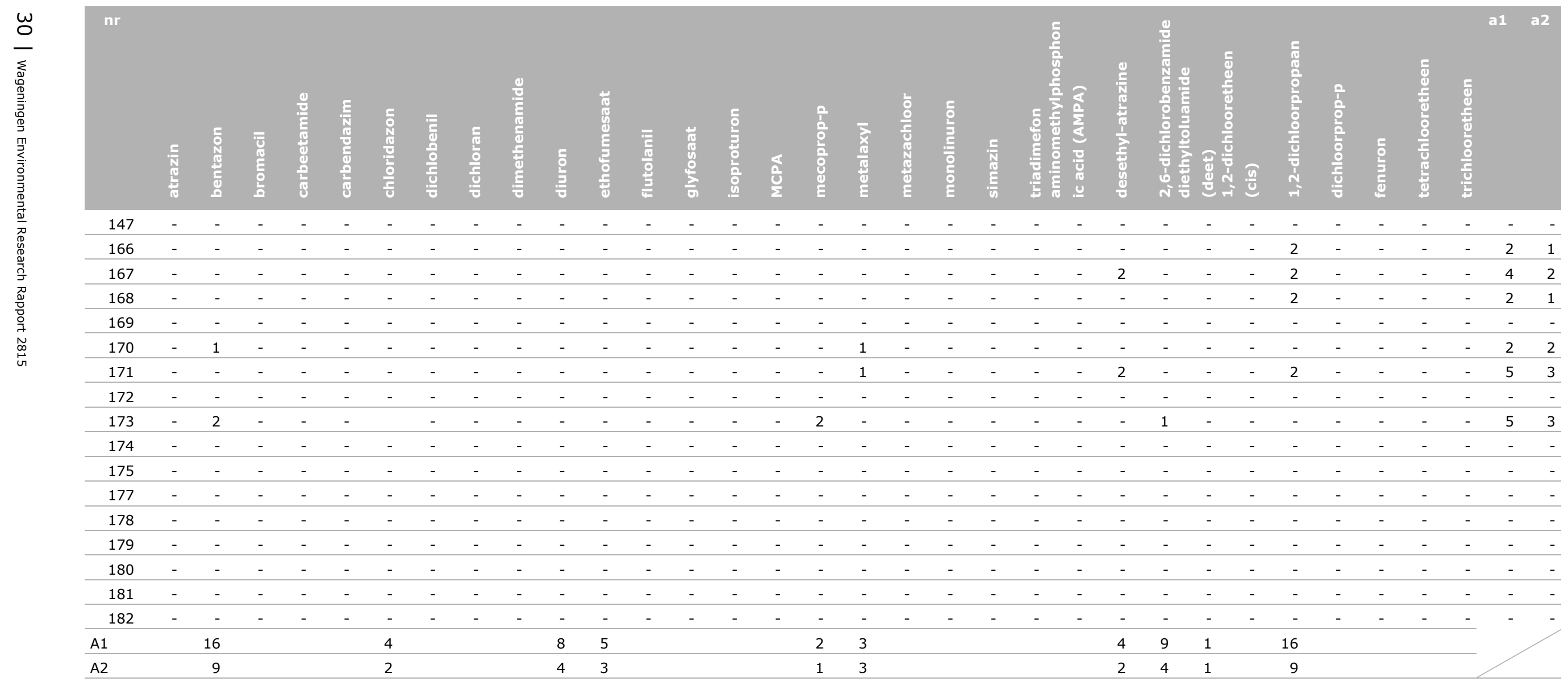


Tabel 1-7 Gemeten concentraties bentazon op ca 10 m diepte (filternr. 1) en de berekende uitspoelingsgevoeligheid op $1 \mathrm{~m}$-mv. ( $\mu \mathrm{g} / \mathrm{L})$.

\begin{tabular}{|c|c|c|c|c|}
\hline \multirow{2}{*}{$\begin{array}{l}\text { putnr. } \\
\text { (filternr. 1) }\end{array}$} & \multirow{2}{*}{$\begin{array}{l}\text { profielnr. } \\
\text { (Tabel 2) }\end{array}$} & \multicolumn{2}{|c|}{ meetwaarde $(\mu \mathrm{g} / \mathrm{L})$} & \multirow{2}{*}{$\begin{array}{r}\text { uitspoelingsgevoeligheid }(\mu \mathrm{g} / \mathrm{L}) \\
\text { (Tabel } 5 \text { ) }\end{array}$} \\
\hline & & 2006 & 2007 gemiddeld & \\
\hline 75 & 4 & & $0.01 \quad 0.01$ & 23 \\
\hline 115 & 4 & 0.01 & 0.02 & 23 \\
\hline 120 & 4 & 0.01 & 0.02 & 23 \\
\hline 129 & 4 & 0.20 & 0.20 & 23 \\
\hline 133 & 4 & 0.01 & 0.01 & 23 \\
\hline 136 & 6 & 0.02 & 0.04 & $<1.0 \mathrm{e}-6$ \\
\hline 170 & 3 & & 0.02 & 13 \\
\hline 173 & 4 & & 0.09 & 23 \\
\hline
\end{tabular}




\section{Bijlage 2 Locatiekenmerken}

Tabel 2-1 Landbouwkundig grondgebruik en natuur volgens $L G N$ en profielnummer volgens de Bodemkaart van Nederland, 1:50 000. Op 32 locaties 4 LGN-opnames in een straal van 50 m (code $V=$ veehouderij, $A=$ akkerbouw, $B=$ bollenteelt, $N=$ natuur). Op de 8 overige locaties LGN4gegevens in een cel van $250 \mathrm{~m} \times 250 \mathrm{~m}$ (code als hierboven, met een inschatting van het percentage). Profielnr. zie Tabel 2.

\begin{tabular}{|c|c|c|c|c|c|c|c|c|c|}
\hline$x$ & y & Putnr & PutCode & Profielnr. & LGN2 & LGN3 & LGN4 & LGN5 & LGN4 \\
\hline 207300 & 539400 & 47 & 16EA3095 & 4 & v & VA & VA & V & - \\
\hline 212450 & 546675 & 55 & $16 \mathrm{FA} 3046$ & 1 & $\mathrm{~N}$ & $\mathrm{~N}$ & $\mathrm{~N}$ & $\mathrm{~N}$ & - \\
\hline 217775 & 526775 & 64 & $16 \mathrm{HA} 3067$ & 5 & v & VA & VA & v & - \\
\hline 219270 & 532130 & 67 & $16 \mathrm{HA} 3107$ & 4 & VA & V & VAO & VA & - \\
\hline 221875 & 533538 & 74 & $17 C A 3157$ & 4 & VA & AV & VOA & VA & - \\
\hline 222837 & 540975 & 75 & 17AA3086 & 4 & VA & V & VAO & v & - \\
\hline 226350 & 567500 & 80 & $12 \mathrm{AA} 3122$ & 4 & VA & VA & VA & AV & - \\
\hline 227770 & 552600 & 82 & 12 CA3097 & 4 & AV & AV & A & A & - \\
\hline 231500 & 540500 & 89 & 17BA3129 & 2 & VA & VA & VA & VA & - \\
\hline 239950 & 567025 & 103 & $12 \mathrm{BA} 3135$ & 1 & v & N & N & $N$ & - \\
\hline 241350 & 548350 & 109 & 17EA3087 & 4 & $\mathrm{~N}$ & $\mathrm{~N}$ & $\mathrm{~N}$ & $\mathrm{~N}$ & - \\
\hline 241700 & 555190 & 110 & $12 \mathrm{GA} 3116$ & 4 & VA & VAO & VA & VA & - \\
\hline 242500 & 528500 & 111 & $17 G A 3088$ & 4 & $\mathrm{AV}$ & AVO & $\mathrm{AV}$ & $\mathrm{AV}$ & - \\
\hline 243500 & 522030 & 113 & 22EA3138 & 4 & VA & v & v & VBOA & - \\
\hline 244250 & 568400 & 115 & 12EA3249 & 4 & VA & VA & VA & VA & - \\
\hline 246550 & 535512 & 120 & $17 G A 3063$ & 4 & VA & VAO & $\mathrm{AV}$ & VAO & - \\
\hline 249160 & 557010 & 123 & $12 \mathrm{GA} 3114$ & 4 & $\mathrm{AV}$ & AV & $\mathrm{AV}$ & AV & - \\
\hline 252000 & 532900 & 129 & 17HA3356 & 4 & VA & VA & VA & vo & - \\
\hline 252740 & 540820 & 131 & 17FA3088 & 4 & AV & AV & AVO & AV & - \\
\hline 256150 & 553688 & 133 & $12 \mathrm{HA} 3085$ & 4 & $\mathrm{AV}$ & AV & $\mathrm{AV}$ & AV & - \\
\hline 256175 & 546238 & 134 & 17FA3072 & 6 & VA & AVO & AVO & AV & - \\
\hline 256675 & 527516 & 136 & $17 \mathrm{HA} 3350$ & 6 & AV & A & A & AV & - \\
\hline 262920 & 532890 & 143 & $18 \mathrm{CA} 3041$ & 6 & $\mathrm{AV}$ & A & $\mathrm{N}$ & $\mathrm{N}$ & - \\
\hline 265620 & 526370 & 147 & $18 C A 3064$ & 6 & $\mathrm{AV}$ & AV & A & AOV & - \\
\hline 241819 & 564541 & 166 & $12 \mathrm{EP} 0258$ & 4 & NAV & NAO & NA & NA & - \\
\hline 248581 & 550170 & 167 & $12 \mathrm{GA} 3115$ & 4 & AVO & AV & VOA & VA & - \\
\hline 245069 & 558075 & 168 & $12 \mathrm{GP} 0104$ & 4 & VAO & VA & VAO & VA & - \\
\hline 210517 & 531929 & 169 & $16 \mathrm{HA} 3088$ & 4 & $\mathrm{AV}$ & V & v & V & - \\
\hline 230740 & 546820 & 170 & 17BA3154 & 3 & $\mathrm{AV}$ & AVO & $\mathrm{AV}$ & VAB & - \\
\hline 251320 & 545680 & 171 & 17FA3086 & 4 & $\mathrm{AV}$ & AV & $\mathrm{AO}$ & $\mathrm{AV}$ & - \\
\hline 255560 & 534600 & 172 & 17HA3359 & 3 & A & AOV & $\mathrm{AV}$ & AV & - \\
\hline 228888 & 520345 & 173 & 22AA3098 & 4 & A & v & VA & v & - \\
\hline 220500 & 537920 & 174 & $17 A A 3102$ & 4 & - & - & - & - & V50A05 \\
\hline 221213 & 566820 & 175 & $12 \mathrm{AA} 3151$ & 4 & - & - & - & - & V50A10 \\
\hline 225680 & 530490 & 177 & 17CA3184 & 4 & - & - & - & - & V40A30 \\
\hline 231380 & 536240 & 178 & 17DA3090 & 3 & - & - & - & - & V40A10 \\
\hline 235970 & 562365 & 179 & $12 \mathrm{DA} 3285$ & 4 & - & - & - & - & V60A20 \\
\hline 239120 & 537180 & 180 & 17DA3091 & 4 & - & - & - & - & A60V15 \\
\hline 246672 & 538705 & 181 & 17EA3088 & 4 & - & - & - & - & A $40 \mathrm{~V} 10$ \\
\hline 248500 & 545070 & 182 & 17EA3089 & 4 & - & - & - & - & A30V20 \\
\hline
\end{tabular}


Tabel 2-2 Enkele locatiekenmerken (PMG, LMG).

\begin{tabular}{|c|c|c|c|c|c|c|c|c|c|c|c|c|c|c|c|c|c|}
\hline Putnr & TR_o & TR_D & HGT & CODE & LETTER & GWT & LGB & KWEL & BODEM & BODEM & ОМ & BG & BT & SL & MV & IJ & VG \\
\hline 47 & - & - & - & - & - & - & - & - & - & - & - & - & - & - & - & - & - \\
\hline 55 & $r$ & $r$ & niz & U16Tnr102-- & U16T & - & natuur/bos & infiltratie & zand & associaties & 28 & Bos & $\mathrm{Za}$ & L1 & 7 & 1978 & St \\
\hline 64 & - & - & - & - & - & - & - & - & - & - & 43 & Gra & $\mathrm{Zr}$ & L9 & 3 & 1978 & In \\
\hline 67 & $r$ & $r$ & giz & $\mathrm{Hn} 23-\mathrm{V}$ & $\mathrm{Hn}$ & v & grasland & infiltratie & zand & veld+laar & - & - & - & - & - & - & - \\
\hline 74 & - & - & - & - & - & - & - & - & - & - & 42 & Bos & $\mathrm{Zr}$ & L9 & 10 & 1978 & St \\
\hline 75 & $r$ & 0 & gtz & $\mathrm{Hn} 23 \mathrm{x}-\mathrm{V}$ & $\mathrm{Hn}$ & V & grasland & intermediair & zand & veld+laar & 30 & Gra & $\mathrm{Zr}$ & L9 & 9 & 1978 & $\mathrm{Kw}$ \\
\hline 80 & $r$ & $r$ & biz & $\mathrm{cHn} 23 \mathrm{x}-\mathrm{VI}$ & $\mathrm{cHn}$ & VI & bouwland & infiltratie & zand & veld+laar & 21 & Bou & $\mathrm{Zr}$ & L1 & 8 & 1983 & St \\
\hline 82 & $r$ & $r$ & biz & Hn21-VII & $\mathrm{Hn}$ & VII & bouwland & infiltratie & zand & veld+laar & - & - & - & - & - & - & - \\
\hline 89 & 0 & 0 & gtz & $\mathrm{Hn} 21-\mathrm{VI}$ & $\mathrm{Hn}$ & VI & grasland & intermediair & zand & veld+laar & 31 & Gra & $\mathrm{Zr}$ & L1 & 13 & 1978 & In \\
\hline 103 & - & - & - & - & - & - & - & - & - & - & 22 & Gra & $\mathrm{Zr}$ & L2 & 5 & 1983 & In \\
\hline 109 & - & - & - & - & - & - & - & - & - & - & - & - & - & - & - & - & - \\
\hline 110 & $r$ & $r$ & giz & Hn21-VII & $\mathrm{Hn}$ & VII & grasland & infiltratie & zand & veld+laar & - & - & - & - & - & - & - \\
\hline 111 & $r$ & 0 & biz & cHn23-VII & $\mathrm{cHn}$ & VII & bouwland & infiltratie & zand & veld+laar & - & - & - & - & - & - & - \\
\hline 113 & - & - & - & - & - & - & - & - & - & - & - & - & - & - & - & - & - \\
\hline 115 & $r$ & $r$ & gtz & U12ORnr116-- & U12OR & - & grasland & intermediair & zand & associaties & 340 & Gra & La & L1 & 1 & 1983 & In \\
\hline 120 & $r$ & o & btz & fvWzt-III & $v W z$ & III & bouwland & intermediair & zand & moerig & 39 & Gra & $\mathrm{Zr}$ & L8 & 17 & 1978 & In \\
\hline 123 & $r$ & $r$ & biz & $\mathrm{Hn} 23 \mathrm{x}-\mathrm{sVI}$ & $\mathrm{Hn}$ & sVI & bouwland & infiltratie & zand & veld+laar & - & - & - & - & - & - & - \\
\hline 129 & $r$ & o & gtz & $\mathrm{Hn} 23 \mathrm{t}-\mathrm{VI}$ & $\mathrm{Hn}$ & VI & grasland & intermediair & zand & veld+laar & - & - & - & - & - & - & - \\
\hline 131 & $r$ & $r$ & biz & cY23x-sVII & cY & sVII & bouwland & infiltratie & zand & dikeerd + mode & - & - & - & - & - & - & - \\
\hline 133 & $\mathrm{~m}$ & $\mathrm{~m}$ & btz & U12ORnr114-- & U12OR & - & bouwland & intermediair & zand & associaties & 34 & Bou & $\mathrm{Zr}$ & L2 & 6 & 1983 & Kw \\
\hline 134 & - & - & - & - & - & - & - & - & - & - & 33 & Bou & $\mathrm{Zr}$ & L7 & 10 & 1983 & In \\
\hline 136 & $r$ & $\mathrm{~m}$ & bk & iVzt-IIIb & iV & IIIb & bouwland & kwel & zand/ veen & veen & 36 & Bou & Ho & LO & 14 & 1987 & $\mathrm{Kw}$ \\
\hline 143 & - & - & - & - & - & - & - & - & - & - & 35 & Bou & Ho & L1 & 14 & 1978 & $\mathrm{Kw}$ \\
\hline 147 & - & - & - & - & - & - & - & - & - & - & - & - & - & - & - & - & - \\
\hline 166 & $r$ & $r$ & biz & Hd21-VIII & $\mathrm{Hd}$ & VIII & bouwland & infiltratie & zand & haar+kamp & - & - & - & - & - & - & - \\
\hline 167 & $r$ & $r$ & biz & Hn23-sVII & $\mathrm{Hn}$ & sVII & bouwland & infiltratie & zand & veld+laar & - & - & - & - & - & - & - \\
\hline 168 & $r$ & $r$ & biz & Hn21-VII & $\mathrm{Hn}$ & VII & bouwland & infiltratie & zand & veld+laar & - & - & - & - & - & - & - \\
\hline 169 & $r$ & $\mathrm{~m}$ & biz & $\mathrm{Hn} 23 \mathrm{x}-\mathrm{V}$ & $\mathrm{Hn}$ & v & bouwland & infiltratie & zand & veld+laar & 186 & Gra & $\mathrm{Zr}$ & L9 & 5 & 1983 & St \\
\hline 170 & $r$ & $r$ & biz & $\mathrm{cHn} 21-\mathrm{VI}$ & $\mathrm{cHn}$ & VI & bouwland & infiltratie & zand & veld+laar & - & - & - & - & - & - & - \\
\hline 171 & $r$ & $r$ & biz & $\mathrm{Hn} 23 \mathrm{x}-\mathrm{sVI}$ & $\mathrm{Hn}$ & sVI & bouwland & infiltratie & zand & veld+laar & - & - & - & - & - & - & - \\
\hline 172 & $r$ & $r$ & biz & cY23x-sVII & cY & sVII & bouwland & infiltratie & zand & dikeerd + mode & - & - & - & - & - & - & - \\
\hline 173 & $r$ & $r$ & giz & $\mathrm{Hn} 23 \mathrm{x}-\mathrm{VI}$ & $\mathrm{Hn}$ & VI & grasland & infiltratie & zand & veld+laar & 44 & Gra & Ho & L6 & 11 & 1978 & In \\
\hline
\end{tabular}




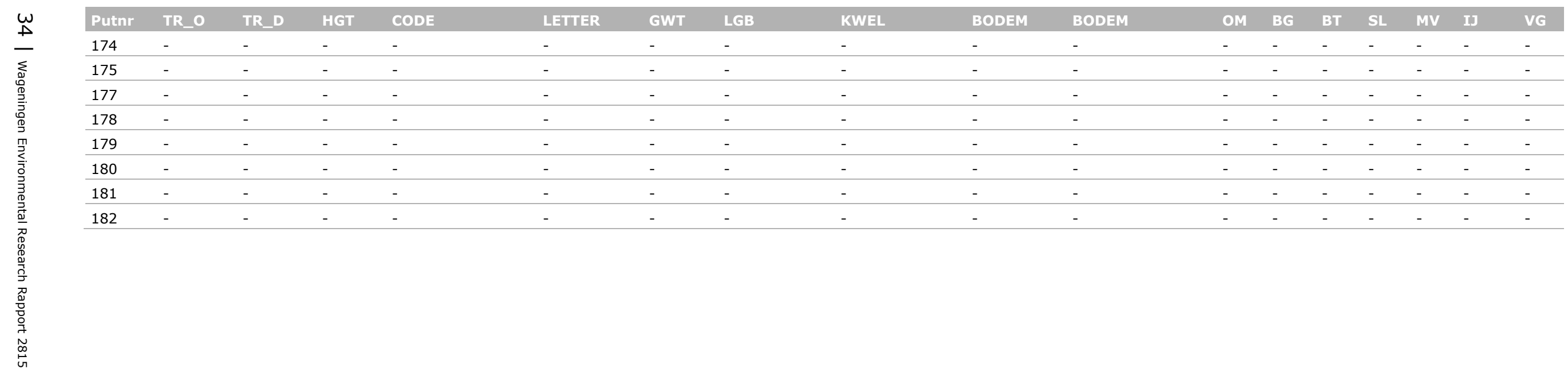




\section{Bijlage 3 Gebruik van stoffen}

Deze bijlage geeft een overzicht van het gebruik van 21 geanalyseerde werkzame stoffen met gegevens in de database NMI 2 .

Bronnen;

1. documentatie verstrekt door de Provincie Drenthe

2. Evaluatie Convenant Openbaar Groen, 2003

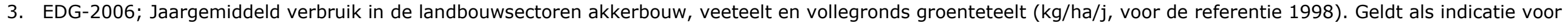
de intensiteit van het gebruik (niet voor stoffen die relatief veel buiten de landbouw worden toegepast)

4. Evaluatie Meerjarenplan Gewasbescherming (MJP-G, 2000, EC-LNV, 2003)

5. ISBEST 2.0 (verbruiksgegevens 1986)

6. Gewasbeschermingsdatabank (www.ctgb.nl)

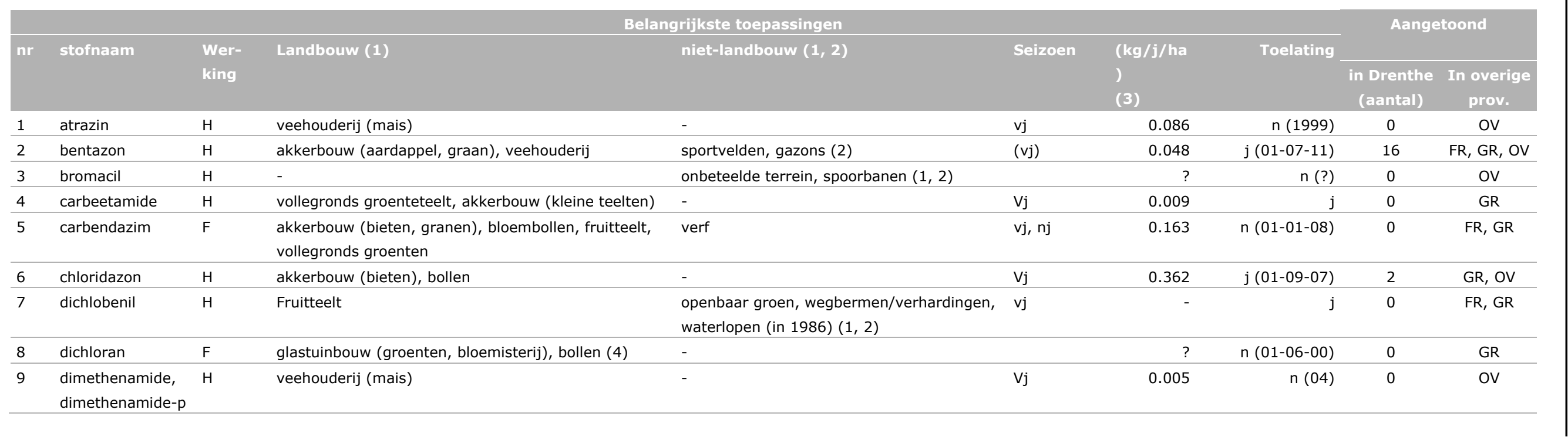



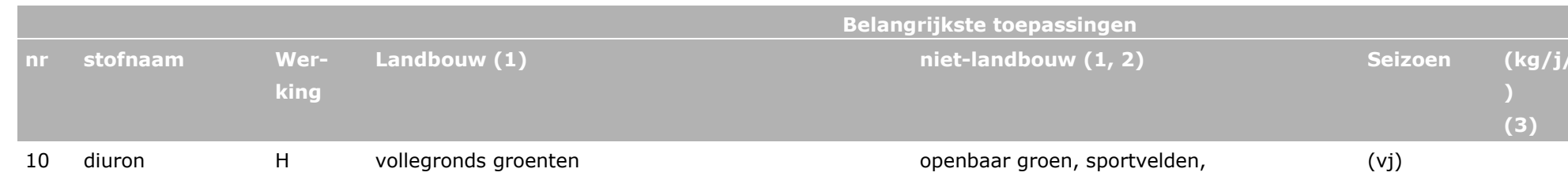

openbaar groen, sportvelden,
verhardingen/permanent onbeteeld terrein

(vj)

$(1,2)$

scheepsverf

\begin{tabular}{lll}
\hline 11 & ethofumesaat & H \\
\hline 12 & flutolanil & $\mathrm{F}$ \\
\hline 13 & glyfosaat & $\mathrm{H}$
\end{tabular}

akkerbouw (bieten, graszaad), veehouderij -

- vj?

vj? $\quad 0.031$

j 2

GR, OV

(grasland), vollegrondsgroente

Akkerbouw, boomkwekerij, bollen (4)

kkerbouw (aardappelen, bieten), veehouderij (mais), Openbaar groen, spoorbanen, onbeteelde

bloembollen, boomkwekerij, fruitteelt, vollegronds

$\mathrm{Vj}$

$0.040 \quad \mathrm{n}(01-05-04)(6)$

terrein, sportvelden, verhardingen $(1,2)$

groenten

Particulier gebruik

\begin{tabular}{|c|c|c|c|c|c|c|c|c|c|}
\hline 14 & isoproturon & $\mathrm{H}$ & akkerbouw (wintertarwe, wintergerst) & - & $\mathrm{nj}$ & 0.122 & j & 0 & OV \\
\hline 15 & MCPA & $\mathrm{H}$ & $\begin{array}{l}\text { akkerbouw (aardappel, graan), veehouderij } \\
\text { (grasland), fruitteelt }\end{array}$ & $\begin{array}{l}\text { Openbaar groen, spoorbanen, sport-velden, } \\
\text { verhardingen, waterlopen (in 1986) (1) }\end{array}$ & $v j ?$ & 0.156 & j & 0 & GR, OV \\
\hline 16 & $\begin{array}{l}\text { mecoprop, } \\
\text { mecoprop-P }\end{array}$ & $\mathrm{H}$ & akkerbouw, veehouderij (grasland) & $\begin{array}{l}\text { Openbaar groen, sport-velden, waterlopen } \\
\text { (in 1986) (2) }\end{array}$ & $v j ?$ & 0.097 & J & 2 & $F R, G R, O V$ \\
\hline 17 & $\begin{array}{l}\text { metalaxyl, } \\
\text { metalaxyl-P }\end{array}$ & $\mathrm{F}$ & $\begin{array}{l}\text { Akkerbouw (aardappelen), groenten (aardbeien), } \\
\text { bloembollen, boomkwekerij }\end{array}$ & - & $\mathrm{vj}$ & 0.062 & n ('99) & 3 & - \\
\hline 18 & metazachloor & $\mathrm{H}$ & Akkerbouw, fruitteelt, boomkwekerij, bollen (4) & - & & 0.005 & $\mathrm{j}$ & 0 & OV \\
\hline 19 & monolinuron & $\mathrm{H}$ & Boomkwekerij & openbaar groen, particulier groen (1) & vj? & 0.088 & $\mathrm{n}(\mathbf{\prime} 00)$ & 0 & ov \\
\hline 20 & simazin & $\mathrm{H}$ & $\begin{array}{l}\text { akkerbouw (kleine teelten), bloembollen, } \\
\text { boomkwekerij, fruitteelt, vollegronds groenten }\end{array}$ & Openbaar groen, verhardingen (2) & $\mathrm{vj}$ & 0.007 & n ('99) & 0 & GR \\
\hline 21 & triadimefon & $\mathrm{F}$ & Boomkwekerij, fruitteelt (5) & - & & - & n (15-09-99) (6) & 0 & ov \\
\hline
\end{tabular}




\section{Bijlage 4 Stofparameters}

De afbraak- en sorptieparameters in de stofdatabase NMI 2 zijn als volgt afgeleid van de gegevens in de dossiers van het Ctgb:

- het geometrisch gemiddelde voor de afbraaksnelheid in de onverzadigde zone (DegT50);

- het rekenkundig gemiddelde voor de sorptiekonstante $\mathrm{K}_{\mathrm{om}}$;

- de maximum waarde voor $\mathrm{K}_{\mathrm{om}, z u u r}$ en minimum waarde voor $\mathrm{K}_{\mathrm{om} \text {, base }}$.

Tabel 4-1 Stofparameters gebruikt in de modelberekeningen. Vet gedrukt zijn mediane waarden ter vervanging van ontbrekende gegevens (stofdatabase NMI 2).

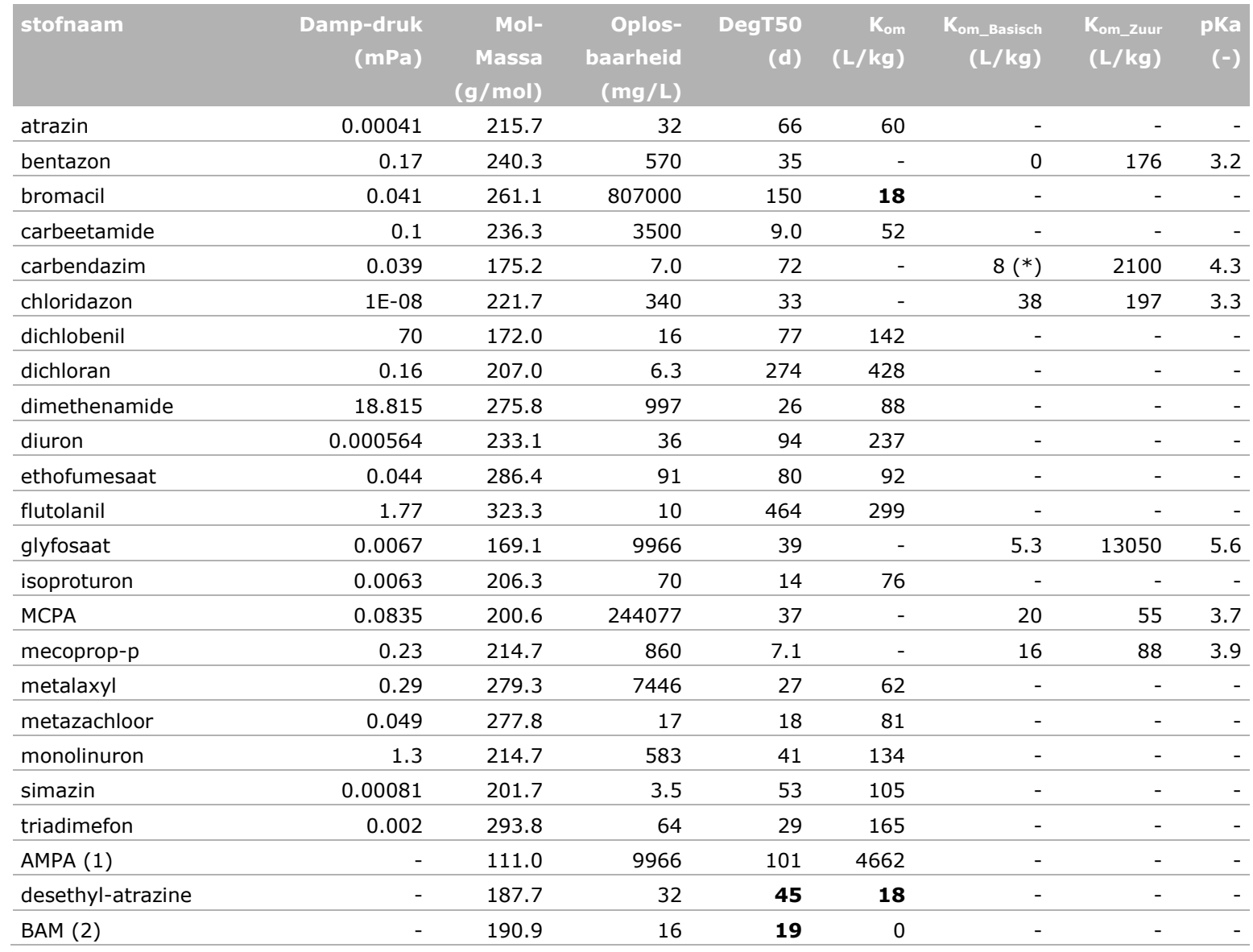

(1) aminomethylphosphonic acid

(2) 2,6-dichlorobenzamide

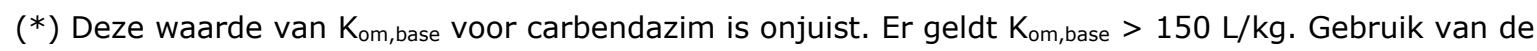
correcte waarde leidt tot een lagere uitspoelingsconcentratie dan gerapporteerd. 


\section{Bijlage 5 Resultaten uitspoelingsberekeningen}

\section{Regionale berekeningen}

Tabel 5-1 Het ruimtelijk 90-percentiel voor 21 werkzame stoffen en 3 metabolieten; landsdekkende berekeningen (NL) en regionale berekeningen voor de Provincie Drenthe (DR); in $\mu g / L$, bij een bodemdepositie = $1 \mathrm{~kg}$ w.s. $/$ ha.

\begin{tabular}{|c|c|c|}
\hline werkzame stof & $\begin{array}{r}\mathrm{NL} \\
(\mu \mathrm{g} / \mathrm{L})\end{array}$ & $\begin{array}{r}\text { DR } \\
(\mu \mathrm{g} / \mathrm{L})\end{array}$ \\
\hline atrazin & 2.5 & 1.0 \\
\hline desethyl-atrazine & 4.4 & 3.4 \\
\hline bentazon & 16 & 12 \\
\hline bromacil & 80 & 82 \\
\hline carbeetamide & $<1.0 \mathrm{e}-6$ & $<1.0 \mathrm{e}-6$ \\
\hline Carbendazim (*) & 31 & $<1.0 \mathrm{e}-6$ \\
\hline chloridazon & 0.38 & 0.029 \\
\hline dichlobenil & 0.055 & 0.0050 \\
\hline BAM & 17 & 19 \\
\hline dichloran & 0.043 & 0.00017 \\
\hline dimethenamide & 0.000067 & 0.0000015 \\
\hline diuron & 0.0036 & 0.00011 \\
\hline ethofumesaat & 1.0 & 0.32 \\
\hline flutolanil & 6.4 & 0.66 \\
\hline glyfosaat & $<1.0 \mathrm{e}-6$ & 0 \\
\hline AMPA & $<1.0 \mathrm{e}-6$ & 0 \\
\hline isoproturon & $<1.0 \mathrm{e}-6$ & $<1.0 \mathrm{e}-6$ \\
\hline MCPA & 3.8 & 1.7 \\
\hline mecoprop-p & 0.000017 & $<1.0 \mathrm{e}-6$ \\
\hline metalaxyl & 0.0048 & 0.00076 \\
\hline metazachloor & $<1.0 \mathrm{e}-6$ & $<1.0 \mathrm{e}-6$ \\
\hline monolinuron & 0.00012 & 0.0000020 \\
\hline simazin & 0.029 & 0.0038 \\
\hline triadimefon & $<1.0 \mathrm{e}-6$ & $<1.0 \mathrm{e}-6$ \\
\hline
\end{tabular}

(*) Gebruik van de correcte waarde van $\mathrm{K}_{\mathrm{om}}$,base voor carbendazim leidt tot een lagere uitspoelingsconcentratie dan gerapporteerd. 

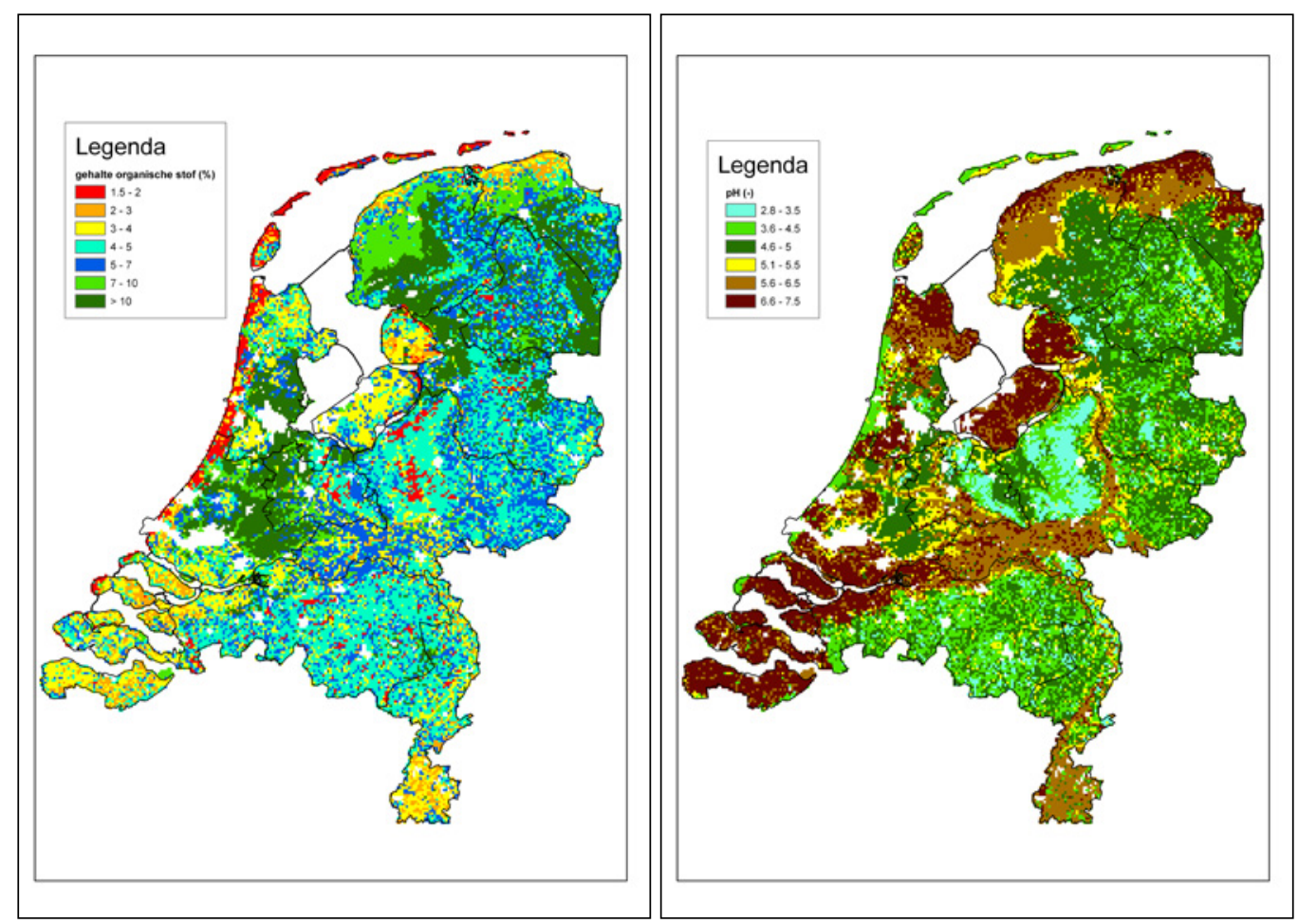

Figuur 5-1 Het gehalte organische stof en de $\mathrm{pH}-\mathrm{KCl}$ in de bovengrond $(0-5 \mathrm{~cm})$.

\section{Voorbeeldberekeningen voor bentazon}

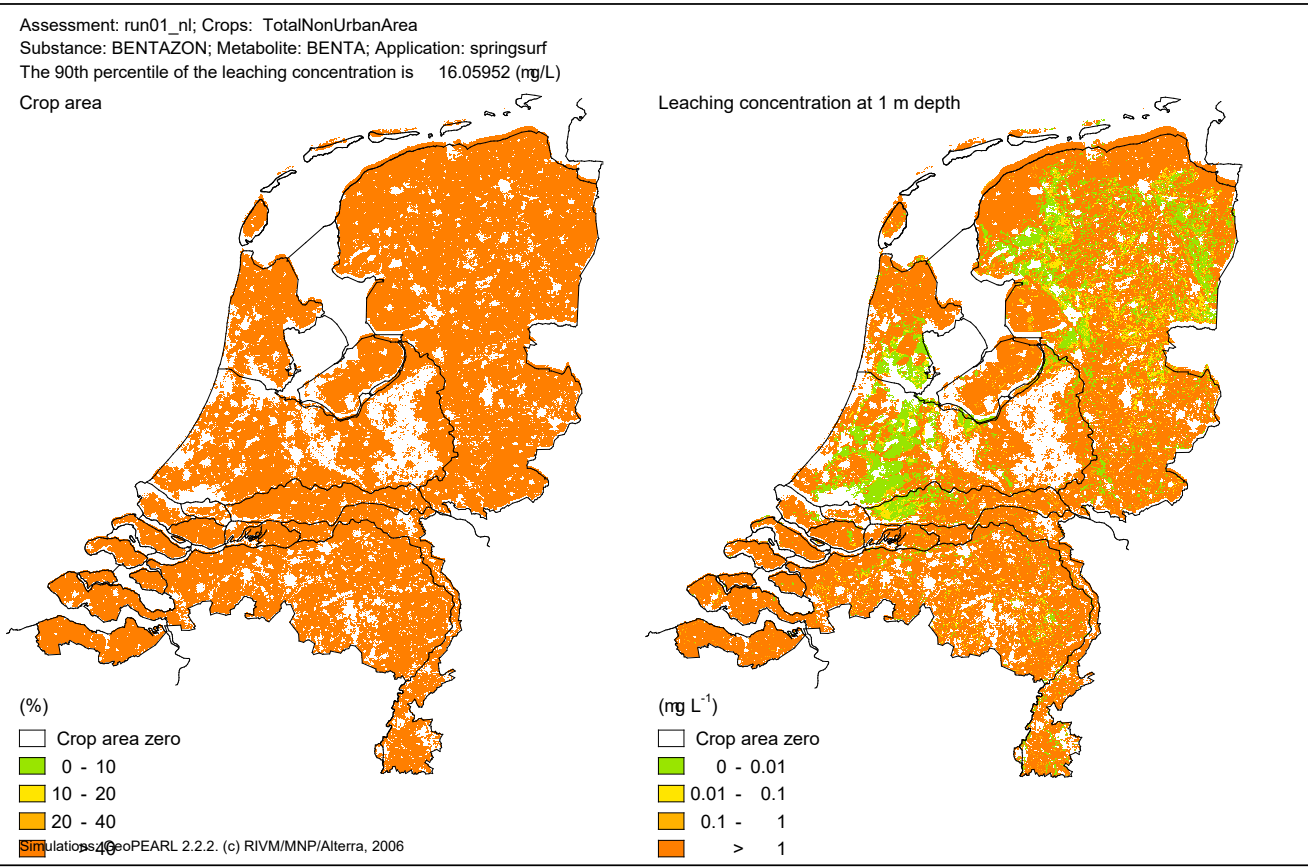

Figuur 5-2 Nederland (links het oppervlak ruraal/niet-stedelijk gebied en rechts de nominale uitspoelingsconcentratie op $1 \mathrm{~m}-\mathrm{mv}$, $(\mu \mathrm{g} / \mathrm{L}$, bij een bodemdepositie $=1 \mathrm{~kg}$ w.s. $/ \mathrm{ha})$. 


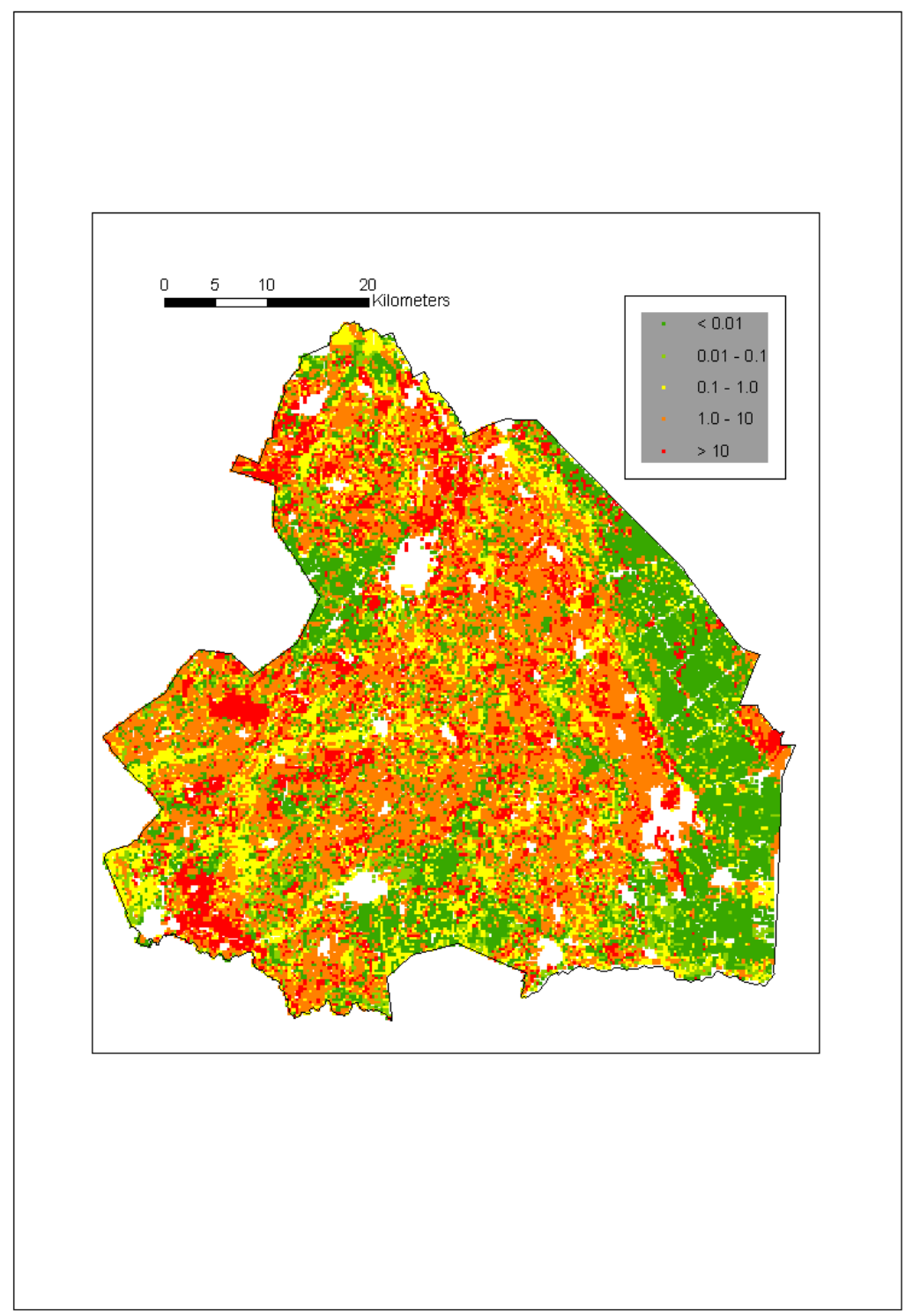

Figuur 5-3 Drenthe; nominale uitspoelingsconcentratie bentazon op $1 \mathrm{~m}-\mathrm{mv}(\mu \mathrm{g} / \mathrm{L}$, bij een bodemdepositie = $1 \mathrm{~kg}$ w.s. $/ \mathrm{ha}$ ). 


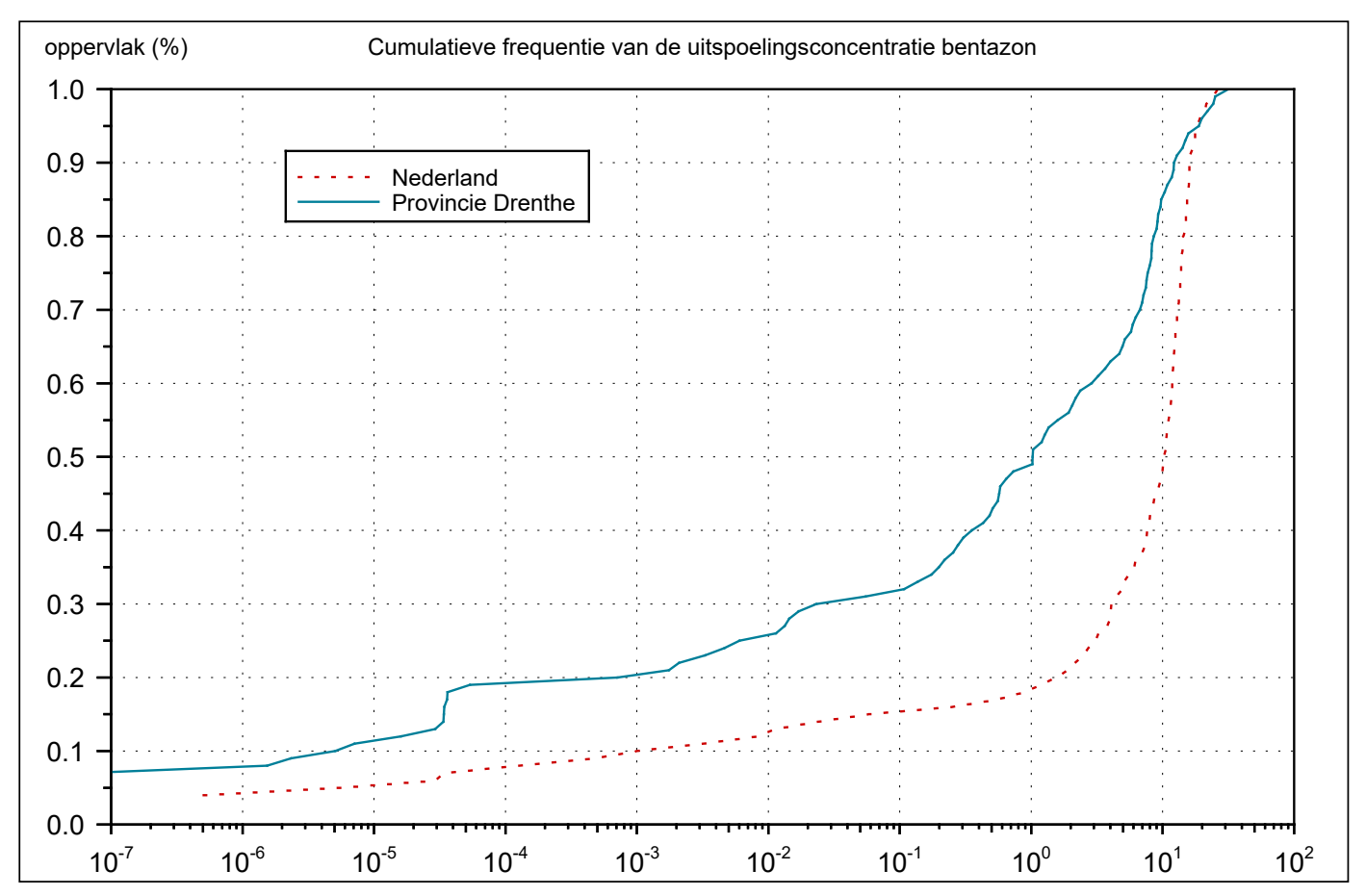

Figuur 5-4 De cumulatieve frequentie van de uitspoelingsconcentratie bentazon, berekend voor Nederland en voor de Provincie Drenthe (nominale concentratie op $1 \mathrm{~m}-\mathrm{mv}$; in $\mu \mathrm{g} / \mathrm{L}$ ). 
Wageningen Environmental Research Postbus 47

6700 AA Wageningen

T 0317480700

www.wur.nl/environmental-research

Wageningen Environmental Research Rapport 2815

ISSN 1566-7197
De missie van Wageningen University \& Research is 'To explore the potential of nature to improve the quality of life'. Binnen Wageningen University \& Research bundelen Wageningen University en gespecialiseerde onderzoeksinstituten van Stichting Wageningen Research hun krachten om bij te dragen aan de oplossing van belangrijke vragen in het domein van gezonde voeding en leefomgeving. Met ongeveer 30 vestigingen, 5.000 medewerkers en 10.000 studenten behoort Wageningen University \& Research wereldwijd tot de aansprekende kennisinstellingen binnen haar domein. De integrale benadering van de vraagstukken en de samenwerking tussen verschillende disciplines vormen het hart van de unieke Wageningen aanpak. 



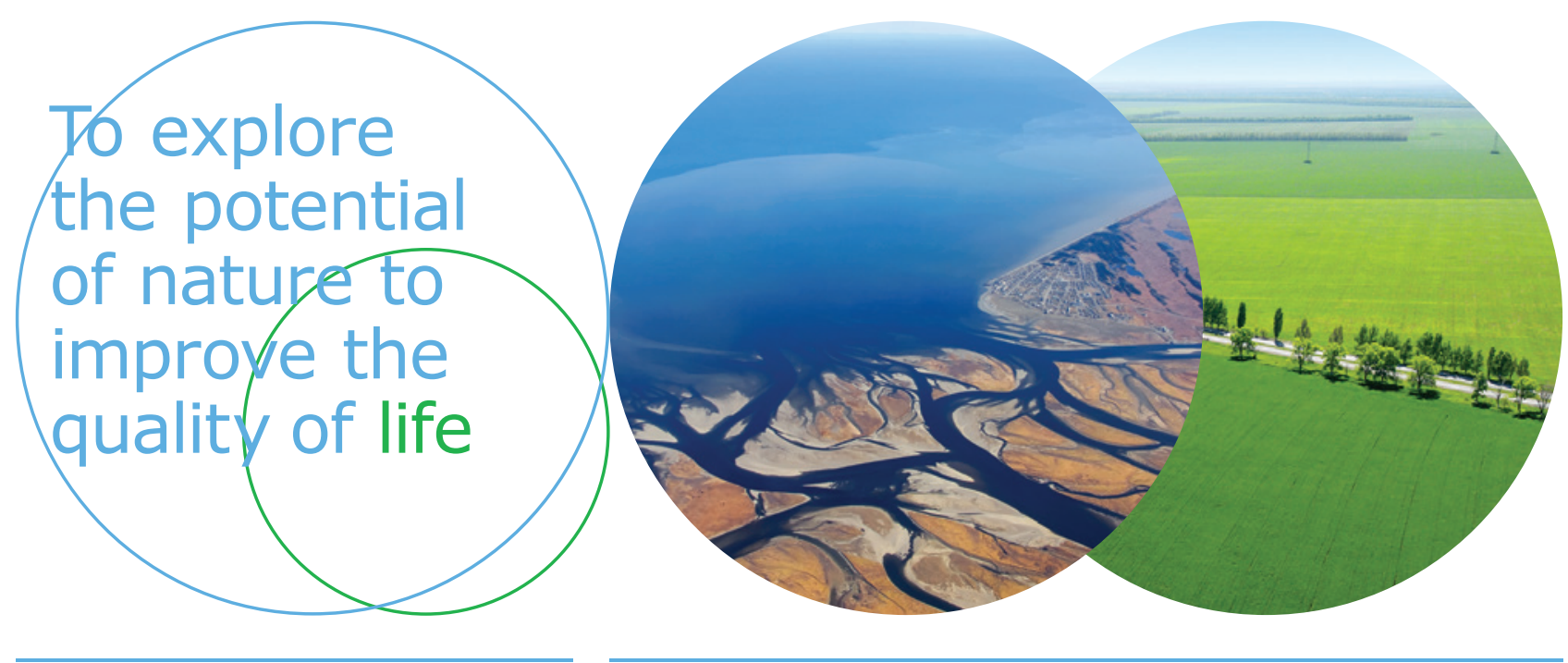

Wageningen Environmental Research Postbus 47

$6700 \mathrm{AB}$ Wageningen

T 317480700

www.wur.nl/environmental-research

Rapport 2815

ISSN 1566-7197
De missie van Wageningen University \& Research is 'To explore the potential of nature to improve the quality of life'. Binnen Wageningen University \& Research bundelen Wageningen University en gespecialiseerde onderzoeksinstituten van Stichting Wageningen Research hun krachten om bij te dragen aan de oplossing van belangrijke vragen in het domein van gezonde voeding en leefomgeving. Met ongeveer 30 vestigingen, 5.000 medewerkers en 10.000 studenten behoort Wageningen University \& Research wereldwijd tot de aansprekende kennisinstellingen binnen haar domein. De integrale benadering van de vraagstukken en de samenwerking tussen verschillende disciplines vormen het hart van de unieke Wageningen aanpak. 